DOI: https://doi.org/10.47405/mjssh.v5i10.520

\begin{tabular}{|c|c|}
\hline 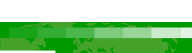 & Malaysian Journal of Social Sciences and Humanities (MJSSH) \\
\hline Malaysian Journal of & Volume 5, Issue 10, October 2020 \\
\hline (MJ . SSH) & e-ISSN : 2504-8562 \\
\hline & $\begin{array}{c}\text { Journal home page: } \\
\text { www.msocialsciences.com }\end{array}$ \\
\hline
\end{tabular}

\title{
Perkaitan antara Motivasi dan Prestasi Kerja Terhadap Kepuasan Kerja dalam kalangan Penjawat Awam
}

\author{
Fadzin Nazirin Bin Mihat', Mohammad Mujaheed Hassan1, Farah Husna Anwar1 \\ 1Jabatan Sains Kemasyarakatan dan Pembangunan, Fakulti Ekologi Manusia, Universiti Putra Malaysia (UPM) \\ Correspondence: Mohammad Mujaheed Hassan (mujaheed@upm.edu.my)
}

\begin{abstract}
Abstrak
Penjawat awam adalah sumber yang membantu organisasi dalam menjalankan pentadbiran dan mencapai matlamat. Penjawat awam memainkan peranan penting dalam menentukan kejayaan atau kegagalan organisasi. Modal insan berkualiti memainkan peranan penting dalam menentukan hala tuju penjawat awam dan memastikan pengurusan yang cekap. Penyelidik secara bertujuan digunakan untuk menetapkan maklumat dan ciri tertentu yang perlu ada pada sampel kajian yang dilakukan. Hasil kajian ini diperoleh melalui pengedaran borang soal selidik kepada responden. Analisis telah dibuat dengan merujuk kepada semua persoalan dan objektif kajian pada bab satu. Kesemua maklumbalas daripada 136 orang responden telah diproses dan dianalisis dengan menggunakan Statistical Package for Social Science (SPSS) version 20 untuk menilai peratus, kekerapan, korelasi, T-test dan Anova. Purata nilai pembolehubah motivasi, prestasi kerja dan kepuasan kerja menunjukkan bahawa tahap prestasi bagi kakitangan awam di MAMPU, Putrajaya berada pada tahap yang tinggi. Secara keseluruhan, faktor demografi jantina, serta status perkahwinan tidak mempengaruhi motivasi, prestasi kerja, dan kepuasan kerja. Namun, faktor demografi yang lain mempengaruhi kesemua pembolehubah. Hasil kajian regresi berganda menunjukkan bahawa nilai $\mathrm{R}$ square bagi pembolehubah tidak bersandar adalah sebanyak 0.367 , manakala nilai adjusted $\mathrm{r}$ square adalah 0.358. Nilai $\mathrm{R}$ square yang tinggi menunjukkan hubungan yang kuat antara pembolehubah tidak bersandar dan pembolehubah bersandar. Berdasarkan Jadual 4.22, menunjukkan bahawa pembolehubah ini signifikan (sig. $=0.000, \mathrm{p}<0.05)$ dengan nilai $\mathrm{F}$ sebanyak 38.612. Motivasi mempunyai nilai beta 0.517 dan prestasi kerja mempunyai nilai beta sebanyak 0.549 . Kedua-dua pembolehubah tidak bersandar adalah signifikan, namun prestasi kerja menunjukkan nilai beta yang tinggi berbanding nilai beta bagi motivasi. Justeru, dapat disimpulkan bahawa prestasi kerja mempunyai hubungan yang kuat dengan kepuasan kerja.
\end{abstract}

Kata kunci: penjawat awam, prestasi kerja, motivasi, kepuasan kerja

\section{The Relationship Between Motivation and Job Performance on Job Satisfaction among Civil Servants}

\begin{abstract}
Civil servants are resources that assist organizations in carrying out administration and achieving goals. Civil servants play an important role in determining the success or failure of an organization. Quality human capital plays an important role in determining the direction of civil servants and ensuring efficient management. Researchers are purposefully used to determine the specific information and features that should be present in the study sample conducted. The results of this study were obtained through the distribution of questionnaires to respondents. The analysis was made with reference to all
\end{abstract}


the questions and objectives of the study in chapter one. All responses from 136 respondents were processed and analyzed using Statistical Package for Social Science (SPSS) version 20 to assess the percentage, frequency, correlation, T-test and Anova. The average values of the variables of motivation, job performance and job satisfaction indicate that the level of performance for civil servants in MAMPU, Putrajaya is at a high level. Overall, gender demographic factors, as well as marital status did not affect motivation, job performance, and job satisfaction. However, other demographic factors influence all variables. The results of the double regression study show that the value of $\mathrm{R}$ square for the independent variable is 0.367 , while the value of adjusted $\mathrm{r}$ square is 0.358 . The high $\mathrm{R}$ square value indicates a strong relationship between the independent variable and the dependent variable. Based on Table 4.22, it shows that this variable is significant (sig. $=0.000, \mathrm{p}$ $<0.05$ ) with an $F$ value of 38.612. Motivation has a beta value of 0.517 and work performance has a beta value of 0.549 . Both independent variables were significant, but work performance showed higher beta values compared to beta values for motivation. Thus, it can be concluded that the job performance has a strong relationship with job satisfaction.

Keywords: civil servant, job performance, motivation, job satisfaction

\section{Pengenalan}

Penjawat awam adalah sumber yang membantu organisasi dalam menjalankan pentadbiran dan mencapai matlamat. Penjawat awam memainkan peranan penting dalam menentukan kejayaan atau kegagalan organisasi. Jabatan kerajaan yang memberikan penawaran yang terbaik, menarik, memotivasi dan memberi penghargaan kepada penjawat awam berdasarkan kemampuan dan kecekapan mereka cenderung untuk kurang mengalami pergantian pekerja. Oleh itu, kajian yang banyak telah dilakukan untuk menilai kesan motivasi dan prestasi terhadap kepuasan kerja. Tujuan utama kajian ini adalah untuk menganalisis hubungan antara pemboleh ubah bebas dan pemboleh ubah bersandar.

Dalam kajian ini, motivasi dan prestasi kerja akan menjadi pemboleh tidak bersandar dan kepuasan kerja sebagai pemboleh ubah bersandar. Kedua-dua pemboleh tidak bersandar ini akan dikaji sama ada ia mempunyai pengaruh terhadap kepuasan kerja. Kepuasan kerja sangat penting dalam sesebuah organisasi kerana itulah yang membuat pekerja mengekalkan pekerjaan yang sedang mereka kerjakan. Oleh kerana itu, majikan mesti tahu apa yang harus di persiapkan untuk pekerja mereka bagi memastikan mereka berpuas hati dengan kedudukan mereka. Majikan perlu memberikan motivasi yang mencukupi bagi meningkatkan prestasi kerja agar pekerja mempunyai perasaan puas dalam menghargai pekerjaan mereka.

Modal insan berkualiti memainkan peranan penting dalam menentukan hala tuju penjawat awam dan memastikan pengurusan yang cekap. Oleh itu, sektor awam mesti cekap dalam memastikan penyampaian perkhidmatan yang berkualiti. Menurut Murphy (1990) dalam Rambli (2001), prestasi kerja dilihat sebagai satu set tingkah laku yang relevan dengan pencapaian matlamat organisasi atau unit organisasi tempat anda bekerja. Menurut Neol (2009) dipetik dalam Nordin dan Hassan (2019: A), mendefinisikan prestasi sebagai proses di mana pengurus bertanggungjawab untuk memastikan bahawa aktiviti dan produktiviti pekerja sesuai dengan matlamat organisasi. Di sektor awam, pentadbir telah menyarankan budaya kerja berdasarkan prestasi dengan penggunaan Petunjuk Prestasi Utama (KPI) diterapkan dalam perkhidmatan awam untuk meningkatkan kualiti penyampaian perkhidmatan. Sejajar dengan visi, misi dan fungsi agensi, setiap organisasi perlu mengukur prestasi perkhidmatan yang diberikan untuk memastikan semua perkhidmatan disampaikan kepada pelanggan dengan baik. Ini seterusnya, dapat memberikan gambaran yang jelas mengenai prestasi organisasi secara keseluruhan.

Petunjuk Prestasi utama (KPI) adalah sistem pengukuran yang mudah, berkesan dan membantu organisasi menentukan dan mengawal kemajuan proses perkhidmatan yang disampaikan kepada pelanggan sesuai dengan misi dan visi organisasi (Pekeliling Pentadbiran Pembangunan No. 2 tahun 
2005 di dalam Nordin dan Hassan (2019: B). Prinsip KPI adalah sasaran, dapat diukur dalam bentuk angka, diukur dalam kondisi normal dan sesuai dengan misi dan visi organisasi. KPI adalah ukuran tertentu dalam bidang prestasi organisasi tertentu. Dalam kajian tersebut, "Hubungan kepuasan kerja dan prestasi kerja di kalangan pekerja dalam industri pembuatan" oleh Rambli bin Haji Hasbi pada tahun 2001, beberapa petunjuk sebagai tanda ukuran prestasi pekerja telah dikenalpasti yang mana tahap kehadirannya, ketepatan masa tugas, disiplin di tempat kerja, kuantiti kerja, kualiti kerja dan semangat kerjasama. Namun, khususnya bagi pekerja sektor awam, berdasarkan Laporan Penilaian Prestasi Tahunan (LNPT) yang diperoleh dari Jabatan Perkhidmatan Awam (JPA), kriteria yang digunakan untuk mengukur prestasi pekerja adalah pengurusan, pengeluaran, pengetahuan dan kemahiran, kualiti peribadi, hubungan dan kerjasama serta aktiviti dan sumbangan.

Menurut Holpp (2012), penilaian prestasi adalah salah satu alat penting yang digunakan oleh pengurus untuk menyelaraskan prestasi pekerja agar selaras dengan matlamat organisasi. Dalam konteks organisasi masa kini, penilaian prestasi adalah pendekatan yang berkesan untuk meningkatkan kualiti perkhidmatan, produktiviti dan memudahkan pencapaian matlamat organisasi (Bohlander, Snell dan Sherman 2001). Menurut laporan dalam Pekeliling Perkhidmatan Bilangan 8 Tahun 2011, sistem penilaian prestasi untuk penjawat awam pada masa ini berdasarkan Pekeliling No. 4 tahun 2002. Penambahbaikan sistem penilaian yang ada juga telah dilaksanakan melalui Pekeliling Perkhidmatan Bilangan 2 tahun 2009 mengenai Memperkukuhkan Pengurusan Sistem Penilaian Prestasi Kakitangan Perkhidmatan Awam. Peningkatan aliran proses penstabilan ini merangkumi pengurusan penilaian prestasi, laporan pencapaian dalam Sasaran Tahunan, penunjuk penilaian aktiviti dan sumbangan di luar tugas rasmi, kategori prestasi pekerja dan penjelasan yang mendapat skor 90 peratus dan ke atas. Menurut pernyataan dari portal rasmi Jabatan Perkhidmatan Awam (JPA), sistem penilaian prestasi bermaksud sistem untuk merancang, melaksanakan, mengurus dan menilai prestasi anggota dan matlamat organisasi dalam satu tahun terakhir.

Menurut laporan dalam Surat Pekeliling Perkhidmatan Bilangan 8 Tahun 2011, Sistem Penilaian Prestasi Perkhidmatan Awam diatur oleh dua (2) prinsip dasar: pertama, penilaian secara adil dan telus berdasarkan prestasi / hasil / impak utama di mana sesuai dan perlakuan yang berkaitan dalam melaksanakan tugas dan tanggungjawabnya dan prinsip kedua adalah untuk mendorong persaingan positif untuk meningkatkan kualiti dan produktiviti untuk mencapai objektif organisasi.

Prestasi kerja sangat dipengaruhi oleh faktor luaran dan dalaman pekerja itu sendiri (Nordin dan Hassan (2019: A). Menurut kajian oleh Che Mohd Syaharuddin Che Cob, Bahyah Abdul Halim dan Aziz Amin (2017) yang bertajuk "Faktor-faktor yang mempengaruhi prestasi penjawat awam: kajian secara teori", kajian membuktikan bahawa dalam meningkatkan prestasi kerja, faktor-faktor iaitu keperibadian individu ciri, motivasi, pembelajaran autonomi dan kepemimpinan gaya ketua kumpulan sangat penting dalam mempengaruhi keberkesanan pelbagai aspek prestasi kerja. Di samping itu, menurut Noralai dan Norhasni (2010) dalam kajiannya "Kajian mengenai faktor-faktor yang mempengaruhi komitmen pekerja terhadap organisasi", secara umum, terdapat beberapa faktor dominan yang mempengaruhi komitmen pekerja, iaitu penyelia, minat terhadap pekerjaan, rakan sekerja dan pendapatan.

Menurut Onukwube (2012), kepuasan kerja sangat penting dan menjadi salah satu keprihatinan sebenar mana-mana organisasi kerana membawa kepada hasil seperti prestasi dan kecekapan pekerja, ketidakhadiran dan pergantian kepada organisasi. Sebilangan besar pekerja berpuas hati dengan pekerjaan mereka yang berbeza kerana mereka dipenuhi dengan pekerjaan mereka. Sebenarnya, pekerja menunjukkan tahap kepuasan kerja yang tinggi dan tahap kepuasan yang rendah apabila sifat persekitaran kerja mereka tidak memenuhi keperluan mereka (Bright, 2008). Dalam aspek ekonomi telah menunjukkan sebab-sebab kepuasan kerja tidak dapat dicapai adalah kerana keadaan kerja yang sukar, ganjaran dan pampasan yang rendah, ketiadaan kenaikan pangkat kerja adalah faktor utama yang menjadikan kepuasan kerja adalah mustahil seperti yang ditunjukkan oleh Onukwube (2012).

Menurut Hassan (2009) menganggap penyebab atau penentu kepuasan kerja sebagai faktor motivasi intrinsik yang berkaitan dengan isi kerja, cabaran, kewajiban, pengendalian strategi kerja, dan penguasaan terhadap lingkungan kerja, peluang untuk menggunakan keterampilan, kemampuan dan 
menyumbang dalam pengambilan keputusan. Faktor ekstrinsik yang berkait dengan pampasan pekerja dan kandungan di mana kerja itu dilakukan contohnya membayar, faedah, penghargaan dll. Selain itu, menurut Idemobi et al. (2011) menganggap pengurusan pampasan sebagai instrumen untuk meningkatkan prestasi organisasi. Pekerja yang mengalami jumlah pekerjaan yang tinggi lebih berdedikasi dan bertanggungjawab terhadap tanggungjawab mereka dan melalui latihan dan kemajuan, mereka dapat membuat pilihan secara bebas.

\section{Penyataan Masalah}

Menurut Sokoya (2000), para penyelidik meneliti pemboleh ubah kepada penentu kepuasan kerja dan hasilnya disimpulkan bahawa kepuasan kerja pada dasarnya dipengaruhi oleh motivasi dan prestasi kerja dalam organisasi. Menurut Opkara (2002), dalam penyelidikan mendapati bahawa kepuasan kerja pekerja dipengaruhi oleh faktor-faktor tertentu, misalnya, prestasi kerja, peluang kenaikan pangkat, pekerjaan itu sendiri, hubungan dengan rakan sekerja dan pengawasan. Sistem ganjaran dipandang sebagai elemen yang berlaku dalam mengukur kepuasan kerja para pekerja. Begitu juga penyelidikan lain yang diketuai oleh Frye (2004) dan dianggap bahawa gaji adalah faktor yang paling asas bagi organisasi untuk mengekalkan tenaga kerja yang betul dan mengekalkan untuk jangka masa yang panjang. Selain itu, sistem motivasi pasti berkaitan dengan kepuasan kerja seorang pekerja di organisasi. Kajian lain juga diadakan untuk mengetahui kesan motivasi terhadap kepuasan kerja dan disimpulkan bahawa terdapat hubungan positif antara kepuasan kerja dan motivasi (Nguyen et al., 2003).

Diketahui bahawa prestasi kerja yang rendah adalah penyebab pergantian pekerja (Abassi dan Hollman, 2000). Kajian ini telah menyimpulkan pengambilan pekerja yang tidak produktif, persekitaran kerja yang tidak harmoni, pampasan yang rendah menimbulkan kesan buruk terhadap kepuasan pekerja (Milman, 2002). Selain itu, peningkatan prestasi kerja adalah disebabkan gaji dan faedah tambahan yang lebih baik yang meningkatkan pendapatan pekerja (Beilock dan Capelle, 1990). Selain itu, penyebab ketidakpuasan kerja seperti keadaan kerja yang teruk, ganjaran dan pampasan yang rendah, kekurangan peluang promosi adalah penyebab utama ketidakpuasan kerja tersebut menurut Onukwube (2012). Oleh itu, tahap kepuasan kerja pekerja dapat dinilai dengan menggunakan lima elemen seperti gaji, kenaikan pangkat, kerja itu sendiri, penyelia dan rakan sekerja. Spector (1997) menambah ganjaran luar jangka, faedah tambahan, keadaan operasi dan komunikasi antara elemenelemen ini.

Kajian ini adalah untuk mengkaji bagaimana pekerja di MAMPU, Putrajaya mencapai tahap kepuasan dalam pekerjaan mereka dan faktor apa yang mempengaruhi kepuasan di kalangan pekerja di MAMPU, Putrajaya.

\section{Objektif Kajian}

Objektif utama kajian ini adalah untuk menentukan hubungan antara motivasi dan prestasi kerja terhadap kepuasan kerja di kalangan pekerja di Unit Pemodenan Tadbiran dan Perancangan Pengurusan Malaysia (MAMPU), Jabatan Perdana Menteri, Putrajaya.

Objektif khusus bagi kajian ini adalah untuk:

i. $\quad$ Untuk memperihalkan latak belakang penjawat awam MAMPU yang dikaji;

ii. Untuk mengenalpasti tahap motivasi, prestasi kerja dan kepuasan kerja penjawat awam MAMPU yang dikaji;

iii. Untuk mengenalpasti perkaitan di antara motivasi dan prestasi kerja dengan kepuasan kerja;

iv. Untuk mengkaji perbezaan di antara motivasi, kepuasan kerja dan prestasi kerja dengan latar belakang demografi;

v. Mengenal pasti pembolehubah tidak bersandar antara motivasi dan prestasi kerja yang mempunyai hubungan yang kuat terhadap pembolehubah bersandar kepuasan kerja. 


\section{Kerangka Konseptual}

Rajah 1: Kerangka konseptual untuk kajian

Pembolehubah Terdahulu Pembolehubah Tidak Bersandar Pembolehubah Bersandar

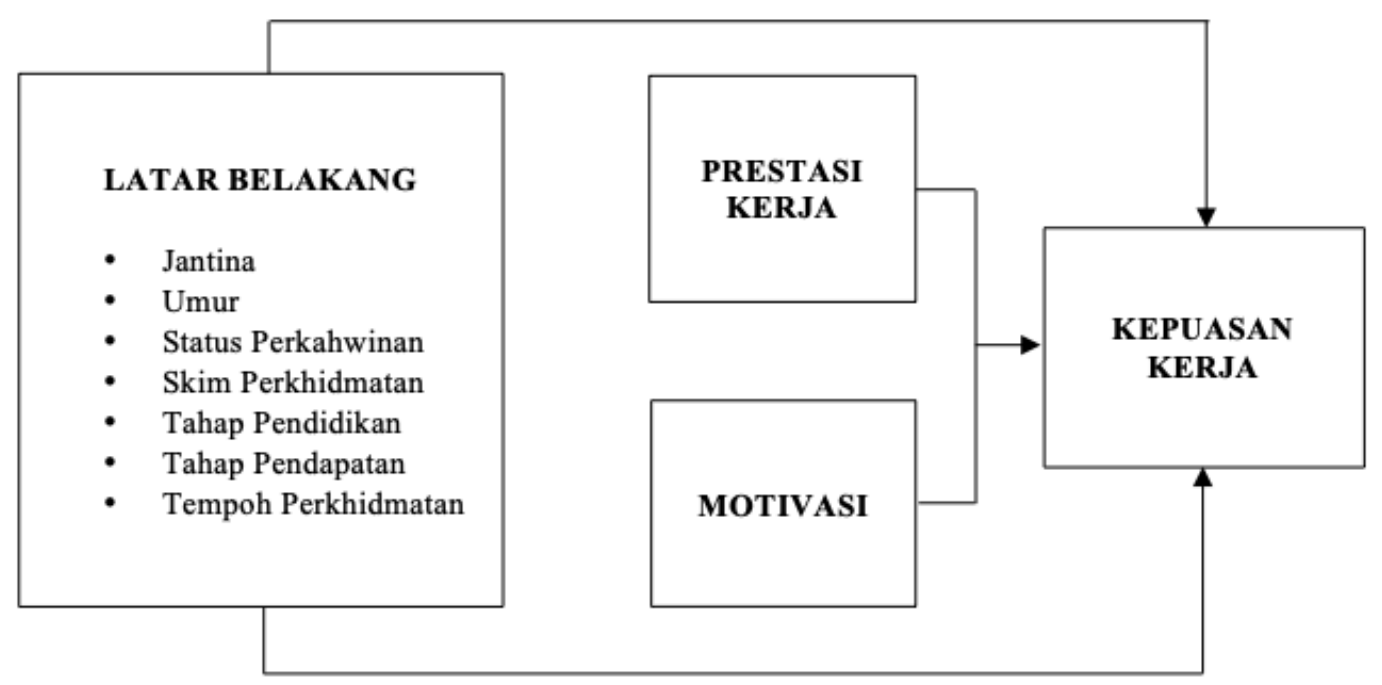

\section{Kajian Literatur}

\section{Kepuasan Kerja}

Kepuasan kerja dapat dicirikan sebagai gabungan keadaan psikologi, fisiologi dan persekitaran yang membuat seseorang secara jujur menyatakan bahawa mereka senang dengan pekerjaan itu (Hoppock, 1935). Seperti yang ditunjukkan oleh pendekatan ini walaupun hakikat bahawa kepuasan kerja dipengaruhi oleh banyak sebab luaran, tetap merupakan sesuatu yang berkaitan dengan perasaan pekerja. Itulah kepuasan kerja menunjukkan susunan faktor yang menimbulkan perasaan puas. Vroom dalam definisi mengenai kepuasan kerja memberi tumpuan kepada peranan pekerja di tempat kerja. Dengan cara ini dia mencirikan kepuasan kerja sebagai orientasi yang berkesan dari pihak individu terhadap peranan kerja yang mereka kerjakan sekarang (Vroom, 1964).

Kepuasan kerja menimbulkan perasaan positif dan negatif terhadap pekerja terhadap pekerjaan mereka. Sementara itu, ketika seorang pekerja dipekerjakan dalam organisasi perniagaan, mereka akan datang dengan keperluan, keinginan dan pengalaman yang menentukan harapan yang telah ditolaknya. Kepuasan kerja menunjukkan sejauh mana harapan dan sesuai dengan penghargaan sebenar. Kepuasan kerja berkaitan dengan tingkah laku pekerja di tempat kerja (Davis et al., 1985). Kepuasan kerja adalah perasaan kejayaan dan prestasi pekerja di tempat kerja. Pada dasarnya, ia dilihat berkaitan secara khusus dengan produktiviti dan kesejahteraan diri.

Kepuasan kerja bermaksud menyelesaikan atau melakukan pekerjaan yang dinikmati oleh seseorang, melakukannya dengan baik dan diberi pampasan atas usaha seseorang. Kepuasan kerja juga menimbulkan kegembiraan dan kebahagiaan dengan pekerjaan seseorang. Kepuasan kerja adalah penentuan kunci yang mendorong pengakuan, upah, kenaikan pangkat, dan pencapaian objektif lain yang menimbulkan perasaan kepuasan (Kaliski, 2007). Kepuasan kerja dapat dicirikan sebagai sejauh mana seseorang pekerja berpuas hati dengan penyelia dan persekitaran yang diperolehnya dari pekerjaan mereka, terutama mengenai motivasi intrinsik (Statt, 2004).

Kepuasan kerja adalah pengumpulan perasaan dan keyakinan yang dimiliki oleh individu mengenai pekerjaan mereka sekarang. Tahap kepuasan kerja individu dapat dijalankan dari kepuasan keterlaluan hingga ketidakpuasan melampau. Selain itu, untuk mempunyai sikap mengenai pekerjaan mereka 
secara umum. Individu juga boleh mempunyai sikap mengenai bahagian pekerjaan yang berbeza, misalnya, jenis pekerjaan yang mereka lakukan, rakan sekerja, penyelia atau bawahan mereka dan pampasan mereka (George et al., 2008). Kepuasan kerja adalah idea yang rumit dan pelbagai aspek yang dapat memberi makna yang berbeza bagi individu yang berbeza. Kepuasan kerja biasanya dihubungkan dengan motivasi, namun idea hubungan ini tidak jelas. Kepuasan tidak sama dengan motivasi. Kepuasan kerja adalah suatu sikap, keadaan dalaman. Contohnya dapat dihubungkan dengan perasaan pencapaian peribadi, baik kuantitatif atau subjektif (Mullins, 2005). Kami menganggap bahawa kepuasan kerja menunjukkan perasaan yang muncul kerana jangkaan bahawa pekerjaan itu memenuhi keperluan material dan psikologi (Aziri, 2011).

Definisi kajian mengenai kepuasan kerja yang paling banyak digunakan adalah oleh Locke (1976), yang mencirikannya sebagai "... Keadaan dalaman yang menyenangkan atau positif yang berasal dari penilaian pekerjaan atau pengalaman kerja seseorang" (hlm. 1304). Yang dapat disahkan dalam definisi Locke adalah kepentingan kedua-dua kesan, atau perasaan, dan kognisi, atau pemikiran. Apabila kita berfikir, kita mempunyai perasaan tentang apa yang kita fikirkan. Sebaliknya, apabila kita mempunyai perasaan, kita memikirkan apa yang kita rasakan. Kognisi dan kesan berkaitan dengan cara ini tidak dapat dipisahkan, dalam psikologi dan bahkan dalam biologi kita. Dengan cara ini, semasa menilai tugas kita, seperti ketika kita menilai apa-apa yang penting bagi kita, pemikiran dan perasaan juga disertakan.

Menurut Jugde et al. (2001) mendapati bahawa ciri keperibadian utama, penilaian kendiri teras, sesuai dengan (berkaitan dengan statistik) kepuasan kerja pekerja. Mereka juga mengetahui bahawa salah satu sebab penting hubungan itu adalah melalui pandangan pekerjaan itu sendiri. Dengan cara ini, menimbulkan kesan bahawa kesan situasi yang paling kritikal terhadap kepuasan kerja adalah pekerjaan itu sendiri dan ia berkaitan dengan apa yang mungkin menjadi sifat keperibadian yang paling penting untuk meramalkan kepuasan kerja, penilaian kendiri teras. (Judge et al.1998).

Persekitaran kerja mungkin digambarkan dalam istilah yang paling sederhana sebagai keadaan, keadaan, keadaan dan situasi di mana individu bekerja. Ia juga dijelaskan oleh Briner, (2000) sebagai kategori yang sangat luas yang merangkumi pengaturan fizikal (contohnya kehangatan, jenis gear dan sebagainya), atribut pekerjaan itu sendiri (misalnya beban kerja, sifat pelbagai aspek), ciri organisasi yang luas (contoh budaya dan sejarah) dan bahkan bahagian dari pengaturan organisasi tambahan (contohnya keadaan ekonomi kerja kejiranan, segmen industri, hubungan rumah-kerja).

Ini menyifatkan bahawa persekitaran kerja sepenuhnya dari hubungan yang ada di antara pekerja dan majikan dan keadaan atau persekitaran di mana pekerja bekerja yang melibatkan keadaan teknikal, manusia dan organisasi. Opperman (2002) merujuk kepada Yusuf dan Metiboba, (2012), untuk mencirikan persekitaran kerja yang terdiri daripada tiga sub-persekitaran utama yang menggabungkan lingkungan teknikal, persekitaran manusia dan persekitaran organisasi. Seperti yang ditunjukkan oleh kamus perniagaan, istilah keadaan kerja merujuk kepada persekitaran kerja dan semua keadaan yang ada mempengaruhi pekerja di tempat kerja, termasuk waktu kerja, aspek fizikal, hak dan tanggungjawab undang-undang, suasana organisasi dan beban kerja.

Konsep persekitaran kerja berasal dari Scandinavia di mana, sejak tahun 1970-an pada umumnya digantikan dengan idea yang lebih sempit mengenai 'kesihatan dan keselamatan pekerjaan,' yang umumnya berkaitan dengan bahaya dan risiko fizikal di tempat kerja. Secara khusus, persekitaran kerja melibatkan konsep 'persekitaran kerja psiko-sosial,' yang bermaksud bagaimana tuntutan pekerjaan dan struktur sosial dan interaksi dalam organisasi mempengaruhi kesejahteraan psikologi pekerja, oleh itu membiarkan pemahaman yang luas tentang bagaimana individu dipengaruhi oleh pekerjaan mereka, termasuk pengalaman kepuasan kerja dan tekanan (Hvid dan Hasle, 2003).

Langkah-langkah yang sering digunakan untuk menentukan persekitaran kerja yang berkualiti adalah langkah-langkah yang menunjukkan aspek penglibatan pekerja di tempat kerja, misalnya, berapa banyak kawalan pekerja terhadap pekerjaan mereka, dan memasukkan kemampuan menyesuaikan diri dalam bagaimana dan kapan tugas diselesaikan (Wood dan Wall, 2007; Gustaffson dan Szebehely, 2009; Sell dan Cleal, 2011), tanpa mengira sama ada pekerja merasa mereka dihargai oleh pihak 
pengurusan (Boxall et al., 2003; Gustaffson dan Szebely, 2009) dan ukuran maklumat mengenai keputusan di tempat kerja yang keprihatinan pekerja (Sell dan Cleal, 2011). Aspek psiko-sosial persekitaran kerja merangkumi konflik, ancaman atau keganasan di tempat kerja (Sell dan Cleal, 2011) dan beban kerja dan tahap tekanan yang dialami (Busck et al., 2010; Sell dan Cleal, 2011).

\section{Motivasi}

Whiseand dan Rush (1988) telah mendefinisikan motivasi sebagai kesediaan seseorang untuk melaksanakan sesuatu dan dikondisikan oleh tindakan untuk memenuhi keperluan. Wegner et al. (2003) kemudian menggambarkan motivasi sebagai sesuatu yang membuat orang mengambil tindakan dan yang berkaitan dengan keputusan yang dibuat oleh individu sebagai sebahagian daripada tingkah laku yang berorientasikan matlamatnya. Mengikuti definisi motivasi semasa adalah intensiti, arah dan usaha berterusan seseorang untuk mencapai tujuan tertentu, disumbangkan oleh Fuller et al. (2008). Berdasarkan pernyataan yang diberikan, dijelaskan lebih lanjut, intensiti adalah seberapa banyak individu berusaha mencapai tujuan atau objektif tertentu sedangkan arah adalah saluran ke intensiti ke arah objektif yang tepat, sementara kegigihan merujuk kepada sejauh mana seseorang terus berusaha untuk mencapai objektif tertentu. Motivasi dicirikan oleh Saraswathi (2011) sebagai kesediaan untuk melakukan usaha yang besar, ke arah matlamat organisasi, yang dikondisikan oleh kemampuan usaha untuk memenuhi keperluan seseorang. Tiga elemen penting dalam definisi juga diberikan sebagai usaha, matlamat organisasi, dan keperluan.

Pelbagai teori motivasi tempat kerja dikategorikan sama ada teori proses atau teori kandungan (Campbell et al., 1970). Merujuk hipotesis Kandungan yang menunjukkan aspek dan keperluan yang menyokong dan memberi inspirasi kepada tingkah laku pekerja dan juga prestasi. Menurut Lynne (2012) kandungan teori motivasi tertumpu pada faktor dalaman pekerja yang merangsang dan mengarahkan tingkah laku kerja mereka. Teori motivasi yang diklasifikasikan di bawah teori kandungan melihat motivasi sebagai hasil dari pemacu dalaman yang membuat orang bertindak atau berusaha untuk memuaskan mereka. Kandungan motivasi terletak pada tindakan yang terbaik dengan perspektif awal dalaman. Hierarki Keperluan Maslow adalah kandungan utama teori motivasi, teori ERG Alderfer, Teori Dua faktor Herzberg, dan Teori Keperluan McClelland (Lynne, 2012). Secara sederhana, teori kandungan bergantung pada banyak faktor yang akan mempengaruhi kepuasan kerja. Teori motivasi yang dikategorikan bahawa semua pekerja dalam organisasi mempunyai syarat yang serupa, kerana itu, memungkinkan organisasi untuk meramalkan kualiti yang seharusnya ada dalam pekerjaan tersebut (Lynne, 2012).

Hubungan motivasi dengan pemboleh ubah bersandar sebagai motivasi memberi kesan positif terhadap kepuasan kerja, dalam tingkah laku organisasi telah mengumpulkan sejumlah besar penyelidikan empirik selama bertahun-tahun. Kedua-dua hubungan ini telah terbukti sebagai faktor sumbangan utama terhadap keberkesanan dan kecekapan organisasi perniagaan. Walaupun kebanyakan penyelidikan empirik telah menyimpulkan penemuan mereka dengan hubungan positif antara Motivasi dan Kepuasan Kerja, serta melengkapkan hubungan antara Motivasi dan Kepuasan Kerja terhadap pemboleh ubah organisasi yang lain.

\section{Prestasi Kerja}

Secara amnya, prestasi kerja dilihat sebagai hasil yang dicapai melalui pekerjaan yang dilakukan. Menurut Murphy (1990) dalam Rambli (2001), prestasi kerja adalah sekumpulan tingkah laku yang relevan dengan pencapaian matlamat organisasi atau unit organisasi tempat anda bekerja. Menurutnya, definisi prestasi harus lebih memusatkan perhatian kepada tingkah laku dan bukannya memfokus pada hasil kerana hasilnya dapat menyebabkan pekerja mencari cara termudah untuk mencapai hasil yang diinginkan, yang mungkin memudaratkan organisasi sebagai tingkah laku penting yang sebaliknya tidak diberi tumpuan oleh pekerja.

Tahap prestasi dapat dicapai dengan program-program tertentu, menentukan tujuan khusus yang ingin dicapai melalui objektif, melalui pengukuran kuantiti dan kualiti menentukan proses operasi, keterampilan, teknologi, keperluan sumber, petunjuk prestasi tersedia untuk mengukur hasil kerja, 
tahap perkhidmatan dan pengeluaran dan mempunyai asas untuk membandingkan hasil program sebenar dengan tujuan prestasi dan menentukan bagaimana mengesahkan nilai yang diukur (Siti Barokah Kasran, 1999). Walau bagaimanapun, Tamkin (2005) berpendapat bahawa prestasi kerja menekankan bahawa individu yang bertindak sendiri tidak dapat meningkatkan prestasi organisasi tetapi hanya melalui kerja berpasukan dalam konteks organisasi. Menurut Matthew (2003), pekerja yang mempunyai kemahiran dan kelayakan yang cenderung menghasilkan prestasi yang tinggi. Nordin dan Hassan (2019:B) dalam kajiannya amendapati bahawa faktor minat dapat memberi hasil kepada prestasi kerja yang baik.

Menurut Bozeman \& Gaughan (2011), persepsi dibayar apa yang bernilai meramalkan kepuasan kerja. Mereka selanjutnya menyatakan bahawa terdapat hubungan signifikan positif antara motivasi dan kepuasan kerja. Kepuasan kerja dianggap sebagai sikap dan tingkah laku individu terhadap aspek pekerjaannya sendiri. Kepuasan kerja peribadi adalah tindak balas afektif atau emosi terhadap pelbagai aspek dan hasil pekerjaan seseorang, yang bermaksud bahawa kepuasan peribadi dalam hubungan dengan pekerjaan tidak bersifat kesatuan, kerana seseorang mungkin berpuas hati dengan satu aspek pekerjaannya dan tidak berpuas hati dengan yang lain.

Telah terbukti dalam beberapa kajian bahawa faktor-faktor yang berkaitan dengan pekerjaan seperti gaji, jam kerja, peluang kenaikan pangkat, keselamatan kerja mempengaruhi kepuasan kerja (Brown et al. 2008; Clark et al. 2009; Pouliakas dan Ioannis, 2010); sama ada pekerjaan itu melibatkan kesukaran, kebosanan atau risiko, (Skalli, et al.2008); sama ada pekerjaan itu menarik, berprestij, atau menuntut (De Jonge dan Wilmar, 1998) dan sama ada pekerjaan itu melibatkan kebebasan pekerja yang sedikit, memberi ruang untuk belajar kemahiran, membolehkan seseorang dapat mencapai prestasi sendiri untuk mendapatkan sesuatu yang berharga (Bockerman dan Ilmakunnas 2009; Clark 1998; Linz 2003). Menurut Nordin dan Hassan (2019: B) perbezaan prestasi kerja boleh berlaku mengikut jantina dan tempoh perkhidmatan. Pekerja yang telah lama berkhidmat mempunyai pengalaman yang lebih luas dan boleh membuat keputusan. (Nordin dan Hassan, 2019: B). Walaupun begitu, penyelidikan yang dilakukan di ekonomi pasar maju, mendapati tindak balas positif atau hubungan untuk gaji, kenaikan pangkat, keselamatan, mencabar, menarik, dengan kepuasan kerja (tindak balas negatif yang berkaitan dengan ketidakpuasan) sedangkan, selama berjam-jam, sukar, kebosanan, risiko terlibat, dan pengawasan yang dekat berkorelasi negatif dengan kepuasan kerja.

\section{Metodologi}

Dalam kajian ini, pengkaji akan menggunakan Penyelidikan Kuantitatif. Penyelidikan kuantitatif menghasilkan maklumat pasaran yang sah secara statistik. Data kuantitatif lebih tepat berbanding dengan data kualitatif. Reka bentuk kajian deskriptif digunakan untuk membantu proses pengumpulan data dan membuat struktur data. Penyelidikan deskriptif menggunakan sekumpulan kaedah dan prosedur saintifik untuk mengumpulkan data dan membuat struktur data yang menggambarkan ciri-ciri seperti jantina, umur, pendapatan, tahap pendidikan dari populasi sasaran. Ini adalah kajian yang bertujuan untuk menggambarkan para peserta dengan tepat. Reka bentuk penyelidikan jenis ini digunakan untuk menerangkan secara sistematik dan tepat fakta dan ciri penduduk atau kawasan tertentu. Kajian deskriptif melaporkan data ringkasan seperti ukuran kecenderungan pusat termasuk min, median, dan mod, penyimpangan dari min, variasi, peratusan, dan korelasi antara pemboleh ubah.

Populasi sasaran kajian ini adalah penjawat awam yang bekerja di Unit Pemodenan Tadbiran dan Perancangan Pengurusan Malaysia (MAMPU), Jabatan Perdana Menteri (JPM), Putrajaya. Kakitangan terdiri daripada Bahagian Khidmat Pengurusan, Bahagian Perancangan dan Komunikasi Korporat, Bahagian Perundingan Pengurusan 1 dan 2, Unit Integriti, dan Bahagian Penyelidikan Pengurusan. Terdapat 136 daripada 256 responden yang dipilih secara rawak mudah di kalangan penjawat awam MAMPU, Putrajaya dan 136 borang soal selidik diedarkan kepada responden.

Untuk penyelidikan ini, skala pengukuran yang digunakan untuk pemboleh ubah adalah skala nominal dan skala Likert. Skala nominal digunakan di bahagian maklumat demografi yang menghendaki responden memilih hanya satu deskriptor sebagai respons mereka. Sementara itu, skala Likert 
digunakan dalam bahagian pemboleh ubah penyelidikan yang merupakan kepuasan kerja, motivasi dan prestasi. Skala Likert digunakan untuk mengkaji seberapa kuat responden setuju atau tidak setuju dengan pernyataan yang diberikan. Skala Likert dirancang dari skala 1, sangat tidak setuju dengan skala 5 yang menunjukkan sangat setuju yang mencerminkan pendapat responden terhadap pernyataan atau soalan yang dinyatakan dalam soal selidik.

Kaedah statistik yang digunakan untuk menganalisis data dalam penyelidikan ini adalah Pakej Statistik untuk Sains Sosial versi 22 (SPSS 22.0). Perisian ini membantu dalam menyunting dan menganalisis segala macam data. Kaedah statistik yang digunakan dalam perisian adalah dalam statistik deskriptif yang memudahkan dalam memahami profil responden yang luas. Ini membantu dalam mengukur frekuensi, tabulasi silang, statistik nisbah deskriptif. Analisis data dilakukan melalui dua peringkat, univariate (statistik deskriptif) dan bivariate (ujian korelasi Pearson, t test dan ujian anova). Selain itu, statistik bivariat yang melakukan analisis varians (ANOVA), bermaksud, korelasi, dan ujian bukan parametrik.

Statistik deskriptif digunakan untuk menjawab objektif pertama, dan kedua iaitu menggambarkan latar belakang, mengenal pasti faktor komitmen kerja utama yang mempengaruhi prestasi kerja dan mengkaji prestasi kerja di kalangan penjawat awam. Data disajikan dari segi nilai frekuensi (f), nilai peratusan (\%) dan nilai purata (mean). Dalam kajian ini, nilai frekuensi (f) dan peratusan (\%) digunakan untuk menganalisis latar belakang responden sementara min (mean) digunakan untuk mengenal pasti purata setiap motivasi dan prestasi untuk menentukan faktor utama yang mempengaruhi kepuasan kerja.

Di samping itu, ujian korelasi Pearson digunakan untuk menentukan hubungan antara dua pemboleh ubah: pemboleh ubah tidak bersandar (motivasi dan prestasi kerja) dan pemboleh ubah bersandar (kepuasan kerja) dan untuk menguji hipotesis yang dibina. Seterusnya untuk menjawab objektif keempat, ujian $\mathrm{t}$ dan anova digunakan. Ujian $\mathrm{t}$ digunakan untuk mengenal pasti perbezaan prestasi kerja mengikut jantina sementara ujian anova digunakan untuk mengenal pasti perbezaan di antara latar belakang demografi dengan motivasi, kepuasan kerja dan prestasi kerja. Objektif kelima adalah mengenal pasti pemboleh ubah tidak bersandar antara motivasi dan prestasi kerja yang mempunyai hubungan yang kuat terhadap pemboleh ubah bersandar kepuasan kerja. Jadual 1 menunjukkan kaedah analisis data terperinci yang digunakan untuk mencapai objektif kajian.

Jadual 1: Kaedah Analisis Data

\begin{tabular}{lll}
\hline No. & Objektif & Analisis Data \\
\hline 1 & $\begin{array}{l}\text { Untuk memperihalkan latak belakang penjawat awam } \\
\text { MAMPU yang dikaji }\end{array}$ & Deskriptif \\
2 & $\begin{array}{l}\text { Untuk menyiasat tahap motivasi, prestasi kerja dan } \\
\text { kepuasan kerja penjawat awam MAMPU yang dikaji. }\end{array}$ & Deskriptif \\
3 & $\begin{array}{l}\text { Untuk mengenal pasti perkaitan di antara motivasi dan } \\
\text { prestasi kerja dengan kepuasan kerja. }\end{array}$ & Ujian Korelasi Pearson \\
& $\begin{array}{l}\text { Untuk mengkaji perbezaan di antara latar belakang } \\
\text { demografi dengan motivasi, kepuasan kerja dan prestasi } \\
\text { keria }\end{array}$ & t test dan Anova test \\
& $\begin{array}{l}\text { Mengenal pasti pemboleh ubah tidak bersandar antara } \\
\text { motivasi dan prestasi kerja yang mempunyai hubungan } \\
\text { yang kuat terhadap pemboleh ubah bersandar kepuasan } \\
\text { kerja. }\end{array}$ & Regresi Berganda \\
\hline
\end{tabular}

Jadual 2 di bawah menunjukan Penentuan Tahap bagi Skor Mean yang digunakan bagi menentukan tahap dalam kajian ini. 
DOI: https://doi.org/10.47405/mjssh.v5i10.520

Jadual 2: Penentuan Tahap bagi Skor Mean

\begin{tabular}{lccccc}
\hline $\begin{array}{l}\text { Skala Likert } \\
\text { Penerangan }\end{array}$ & $\begin{array}{c}\mathbf{1} \\
\text { Sanagt } \\
\text { Tidak } \\
\text { Setuju }\end{array}$ & $\begin{array}{c}\text { Tidak } \\
\text { Setuju }\end{array}$ & Neutral & $\begin{array}{c}\mathbf{4} \\
\text { Setuju }\end{array}$ & $\begin{array}{c}\mathbf{5} \\
\text { Sangat } \\
\text { Setuju }\end{array}$ \\
\hline $\begin{array}{l}\text { Skor Mean } \\
\text { Tahap }\end{array}$ & $\begin{array}{c}\text { 1.00-2.99 } \\
\text { Rendah }\end{array}$ & $\begin{array}{c}3.00 \\
\text { Sederhana }\end{array}$ & \multicolumn{2}{c}{$3.01-5.00$} \\
Tinggi
\end{tabular}

Jadual 3 di bawah menunjukan Kekuatan Hubungan Kolerasi yang digunakan di dalam kajian ini. Realibility test (Cronbach's alpha) dijalankan untuk menilai konsentasi setiap faktor pembolehubah kajian. Jadual 4 menunjukkan soal selidik dalam kajian ini mempunyai 37 item yang berkait dengan dua pembolehubah tidak bersandar iaitu motivasi (5) dan prestasi kerja (13) dan kepuasan bekerja (18) sebagai pembolehubah bersandar. Secara keseluruhan jumlah cronbach's alpha bagi item adalah sebanyak 0.871. Secara umum, nilai cronbach's alpha 0.749 hingga 0.868 untuk 3 pembolehubah dianggap menunjukkan konsistensi dan kebolehpercayaan yang tinggi. Hasil kesahan dan tahap kebolehpercayaan instrumen yang dibina adalah baik kerana nilai cronbach's alpha melebihi 0.7 (a $>0.7)$. Semakin tinggi nilai cronbach's alpha, semakin tinggi kebolehpercayaan instrumen yang dibina.

Jadual 3: Kekuatan Hubungan Korelasi

\begin{tabular}{cl}
\hline Nilai Korelasi (r) & \multicolumn{1}{c}{ Kekuatan Hubungan } \\
\hline .90 to \pm 1.0 & Korelasi positif/negatif yang tinggi \\
\pm .70 to \pm .90 & Korelasi positif/negatif yang tinggi \\
\pm .50 to \pm .70 & Korelasi positif/negatif sederhana \\
\pm .30 to \pm .50 & Korelasi positif/negatif rendah \\
\pm .00 to \pm .30 & Tidak ada korelasi \\
\hline
\end{tabular}

Jadual 4: Keputusan Analisis Kebolehpercayaan (Cronbach's alpha)

\begin{tabular}{lcc}
\hline \multicolumn{1}{c}{ Pembolehubah } & Bilangan Item & Cronbach's Alpha \\
\hline Motivasi & 5 & 0.833 \\
Prestasi Kerja & 13 & 0.749 \\
Kepuasan Kerja & 19 & 0.868 \\
Jumlah Pemboleh Ubah & 36 & 0.871 \\
\hline
\end{tabular}

\section{Dapatan Kajian}

\section{Analisis Latar Belakang Demografi}

Jadual 5 menunjukkan seramai $69(50.7 \%)$ orang responden terdiri daripada kakitangan perempuan manakala $67(49.3 \%)$ orang responden adalah terdiri daripada kakitangan lelaki. Justeru, dapat disimpulkan bahawa penjawat awam di (MAMPU) JPM, Putrajaya didominasi oleh golongan perempuan dan golongan lelaki merupakan minoriti.

Jadual 5: Profil Latar Belakang Demografi Responden

\begin{tabular}{llccc}
\hline Demografi & & Kategori & Frekuensi & Peratusan (\%) \\
\hline Jantina & Lelaki & 67 & 49.3 \\
& Perempuan & 69 & 50.7 \\
& JUMLAH & 136 & 100 \\
\hline
\end{tabular}




\begin{tabular}{llcc} 
Umur & 19 hingga 28 tahun & 30 & 22.1 \\
& 29 hingga 38 tahun & 69 & 50.7 \\
& 39 hingga 48 tahun & 25 & 18.4 \\
& 48 hingga 60 tahun & 12 & 8.8 \\
& JUMLAH & 136 & 100 \\
\hline Status & Bujang & 25 & 18.4 \\
Perkahwinan & Berkahwin & 11 & 81.6 \\
& JUMLAH & 136 & 100 \\
\hline Skim & Pelaksana (Gred 1-40) & 55 & 40.4 \\
Perkhidmatan & Pengurusan dan Profesional (Gred 41-56) & 79 & 58.1 \\
& Pengurusan Tertinggi (JUSA \& TURUS) & 2 & 1.5 \\
& JUMLAH & 136 & 100 \\
\hline Tahap & Sijil Pelajaran Malaysia (SPM) & 15 & 11 \\
Pendidikan & Sijil Tinggi Persekolahan Malaysia (STPM) & 6 & 4.4 \\
Tertinggi & Diploma & 25 & 18.4 \\
& Sarjana Muda & 62 & 45.6 \\
& Ijazah Sarjana & 27 & 19.9 \\
& Doktor Falsafah & 1 & 0.7 \\
& JUMLAH & 136 & 100 \\
\hline Pendaptan & RM1000 - RM4360 (B40) & 92 & 67.6 \\
& RM 4361- RM9620 (M40) & 42 & 30.9 \\
& Lebih dari RM9621 (T20) & 1 & 1.5 \\
& JUMLAH & 136 & 100 \\
\hline Tempoh & 5 tahun dan ke atas & 33 & 24.3 \\
Perkhidmatan & 6-10 tahun & 36 & 26.5 \\
& 11-15 tahun & 36 & 26.5 \\
& 16-20 tahun & 18 & 13.2 \\
& 25 tahun dan ke atas & 13 & 9.6 \\
& JUMLAH & 136 & 100 \\
\hline
\end{tabular}

Merujuk Jadual 6, bagi pecahan taburan umur, majoriti responden adalah berumur 29 hingga 38 tahun, penjawat awam di (MAMPU) JPM, Putrajaya terdiri seramai 69 (55.2\%) orang responden yang terdiri daripada 37 orang lelaki dan 32 orang wanita. Seterusnya, diikuti dengan responden berumur 18 hingga 29 tahun sebanyak $30(22.1 \%)$ orang responden berumur dalam lingkungan 19 hingga 28 tahun dan teridiri daripada 15 orang lelaki dan 15 orang perempuan. Sebanyak 25 (18.4\%) orang responden berumur dalam lingkungan 39 hingga 48 tahun dan terdiri daripada 8 orang lelaki dan 17 orang perempuan. Minoriti responden adalah sebanyak $12(8.8 \%)$ orang responden yang berumur dalam lingkungan 48 hingga 60 tahun dan terdiri sebanyak 7 orang lelaki dan 5 orang perempuan.

Jadual 6: Crosstabulation Jantina dan Umur Responden

\begin{tabular}{llccccc}
\hline & \multirow{2}{*}{ Item } & \multicolumn{4}{c}{ Umur / Tahun } & \multirow{2}{*}{ Jumlah } \\
\cline { 2 - 5 } & & $18-29$ & $29-38$ & $39-48$ & $48-60$ & \\
\hline \multirow{2}{*}{ Lelaki } & $\mathrm{N}$ & 15 & 37 & 8 & 7 & 67 \\
& \% Jantina & 22.4 & 55.2 & 11.9 & 10.4 & 100 \\
& \% Umur & 50 & 53.6 & 32 & 58.3 & 49.3 \\
& $\mathrm{~N}$ & 15 & 32 & 17 & 5 & 69 \\
\multirow{5}{*}{ Perempuan } & \% Jantina & 21.7 & 46.4 & 24.6 & 7.2 & 100 \\
& \% Umur & 50 & 46.4 & 68 & 41.7 & 50.7 \\
& N & 30 & 69 & 25 & 12 & 136 \\
& \% Jantina & 22.1 & 50.7 & 18.4 & 8.8 & 100 \\
& \% Umur & 100 & 100 & 100 & 100 & 100 \\
\hline
\end{tabular}


DOI: https://doi.org/10.47405/mjssh.v5i10.520

Manakala merujuk Jadual 7 iaitu crosstabulation jantina dan status perkahwinan, sebanyak 111 (81.6\%) orang responden yang telah berkahwin dan terdiri daripada 47 lelaki dan 64 orang perempuan. Manakala, sebanyak 25 (18.4\%) orang responden yang belum berkahwin dan terdiri daripada 20 orang lelaki dan 5 orang perempuan. Justeru dapat disimpulkan bahawa majoriti penjawat awam di MAMPU Putrajaya terdiri daripada pekerja yang telah berkahwin.

Jadual 7: Crosstabulation Jantina dan Status Perkahwinan

\begin{tabular}{clccc}
\hline \multirow{2}{*}{ Item } & \multicolumn{2}{c}{ Status Perkahwinan } & \multirow{2}{*}{ Jumlah } \\
\cline { 3 - 4 } Lelaki & Bujang & Berkahwin & \\
\hline \multirow{5}{*}{ Perempuan } & 20 & 47 & 67 \\
& \% Jantina & 29.9 & 70.1 & 100 \\
& \%Status Perkahwinan & 80 & 42.3 & 49.3 \\
& N & 5 & 64 & 69 \\
& \% Jantina & 7.2 & 92.8 & 100 \\
& \% Status Perkahwinan & 20 & 57.7 & 50.7 \\
& N & 25 & 111 & 136 \\
& \% Jantina & 18.4 & 81.6 & 100 \\
& \% Status Perkahwinan & 100 & 100 & 100 \\
\hline
\end{tabular}

Jadual 8 menunjukan crosstabulation jantina dan skim perkhidmatan penjawat awam di MAMPU Putrajaya. Berdasarkan analisis kajian, jumlah responden tertinggi iaitu seramai 79 (58.1\%) orang responden bertugas dalam kategori Pengurusan dan Profesional (Gred 41-56) yang terdiri daripada 41 orang lelaki dan 38 orang perempuan. Seterusnya, sebanyak 55 (40.4\%) orang responden yang bekerja sebagai pelaksana (Gred 1-40) dan terdiri daripada 24 orang lelaki dan 31 orang perempuan. Terdapat seramai $2(1.5 \%)$ orang responden yang bertugas sebagai Pengurusan Tertinggi (JUSA \& TURUS). Secara kesimpulan, minoriti penjawat awam yang berkhidmat di MAMPU Putrajaya adalah terdiri daripada kategori Pengurusan dan Profesional (Gred 41-56).

Jadual 8: Crosstabulation Jantina dan Skim Perkhidmatan

\begin{tabular}{|c|c|c|c|c|c|}
\hline & \multirow[b]{2}{*}{ Item } & \multicolumn{3}{|c|}{ Skim Perkhidmatan } & \multirow[b]{2}{*}{ Jumlah } \\
\hline & & $\begin{array}{c}\text { Pelaksana } \\
\text { (Gred 1-40) }\end{array}$ & $\begin{array}{c}\text { Pengurusan \& } \\
\text { Profesional } \\
\text { (Gred 41-56) }\end{array}$ & $\begin{array}{c}\text { Pengurusan } \\
\text { Tertinggi } \\
\text { (JUSA \& } \\
\text { TURUS) } \\
\end{array}$ & \\
\hline \multirow{3}{*}{ Lelaki } & $\mathrm{N}$ & 24 & 41 & 2 & 67 \\
\hline & $\%$ Jantina & 35.8 & 61.2 & 3 & 100 \\
\hline & \% Skim Perkhidmatan & 43.6 & 51.9 & 100 & 49.3 \\
\hline \multirow{3}{*}{$\begin{array}{l}\text { Perempua } \\
\mathrm{n}\end{array}$} & $\mathrm{N}$ & 31 & 38 & 0 & 69 \\
\hline & $\%$ Jantina & 44.9 & 55.1 & 0 & 100 \\
\hline & \% Skim Perkhidmatan & 56.4 & 48.1 & 0 & 50.7 \\
\hline \multirow{3}{*}{ Jumlah } & $\mathrm{N}$ & 55 & 79 & 2 & 136 \\
\hline & $\%$ Jantina & 40.4 & 58.1 & 1.5 & 100 \\
\hline & $\%$ Skim Perkhidmatan & 100 & 100 & 100 & 100 \\
\hline
\end{tabular}

Taburan tahap pendidikan bagi penjawat awam di MAMPU, Putrajaya juga ditunjukkan dalam Jadual 9. Majoriti responden iaitu seramai $62(45.6 \%)$ orang responden yang terdiri daripada 27 orang lelaki dan 35 orang perempuan mempunyai tahap pendidikan Sarjana muda, seterusnya diikuti dengan seramai 27 (19.9\%) orang responden mempunyai ijazah sarjana dan terdiri daripada 17 orang lelaki dan 10 orang perempuan. Terdapat seramai 14 orang lelaki dan 11 orang perempuan responden yang mempunyai tahap pendidikan diploma iaitu sebanyak $25(18.4 \%)$ orang responden. Sebanyak 15 (11\%) orang responden yang mempunyai Sijil Pelajaran Malaysia (SPM) dan terdiri daripada 7 orang lelaki dan 8 orang perempuan. Selain itu, terdapat seramai 1 orang lelaki dan 5 orang perempuan responden yang mempunyai tahap pendidikan tertinggi pada tahan Sijil Tinggi Pelajaran Malaysia 
(STPM). Minoriti responden mempunyai tahap pendidikan tertinggi adalah sebanyak $1(0.7 \%)$ orang responden mempunyai Doktor Falsafah.

Jadual 9: Crosstabulation Jantina dan Tahap Pendidikan

\begin{tabular}{|c|c|c|c|c|c|c|c|c|}
\hline & \multirow[b]{2}{*}{ Item } & \multicolumn{6}{|c|}{ Tahap Pendidikan } & \multirow[b]{2}{*}{ Jumlah } \\
\hline & & $\sum_{i=1}$ & 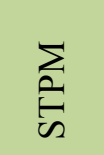 & $\begin{array}{l}\tilde{a} \\
\stackrel{0}{0} \\
\stackrel{0}{0}\end{array}$ & 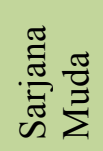 & 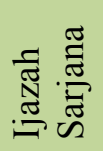 & $\stackrel{\S}{2}$ & \\
\hline & $\mathrm{N}$ & 7 & 1 & 14 & 27 & 17 & 1 & 67 \\
\hline \multirow[t]{3}{*}{ Lelaki } & $\%$ Jantina & 10.4 & 1.5 & 16 & 40.3 & 25.4 & 1.5 & 100 \\
\hline & \%Tahap Pendidikan & 46.7 & 16.7 & 56 & 43.5 & 63 & 100 & 49.3 \\
\hline & $\mathrm{N}$ & 8 & 5 & 11 & 35 & 10 & 0 & 69 \\
\hline \multirow[t]{2}{*}{ Perempuan } & $\%$ Jantina & 11.6 & 7.2 & 15.9 & 50.7 & 14.5 & 0 & 100 \\
\hline & \%Tahap Pendidikan & 53.3 & 83.3 & 44 & 56.5 & 37 & 0 & 50.7 \\
\hline \multirow{3}{*}{ Jumlah } & $\mathrm{N}$ & 15 & 6 & 25 & 62 & 27 & 1 & 136 \\
\hline & $\%$ Jantina & 11 & 4.4 & 18.4 & 45.6 & 19.9 & 0.7 & 100 \\
\hline & \%Tahap Pendidikan & 100 & 100 & 100 & 100 & 100 & 100 & 100 \\
\hline
\end{tabular}

Jadual 10 menunjukkan analisis kajian bagi latar belakang demografi (Pendapatan) dalam kalangan penjawat awam di MAMPU, Putrajaya. Berdasarkan jadual tersebut, majoriti responden adalah tergolong dalam B40 kerana mempunyai pendapatan sebanyak RM 1000 hingga RM 4360, iaitu sebanyak $92(67.6 \%)$ orang responden. Majoriti responden tersebut terdiri daripada 38 orang lelaki dan 54 orang perempuan. Seterusnya, diikuti dengan responden yang mempunyai pendapatan sebanyak RM 4361 hingga RM 9620 (M40) dan terdiri daripada 27 orang lelaki dan 15 orang wanita. Akhir sekali, hanya terdapat 2 orang responden lelaki yang mempunyai pendapatan lebih dari RM 9621 dan tergolong dalam golongan T20.

Jadual 10: Crosstabulation Jantina dan Pendapatan

\begin{tabular}{clcccc}
\hline \multirow{5}{*}{ Item } & \multicolumn{3}{c}{ Pendapatan } & \\
\cline { 3 - 5 } & & $\begin{array}{c}\text { RM1000- } \\
\text { RM4360 } \\
(\mathrm{B} 40)\end{array}$ & $\begin{array}{c}\text { RM4361 } \\
\text { RM9620 } \\
(\mathrm{M} 40)\end{array}$ & $\begin{array}{c}\text { Lebih dari } \\
\text { RM9621 } \\
(\mathrm{T} 20)\end{array}$ & Jumlah \\
\hline \multirow{2}{*}{ Lelaki } & $\mathrm{N}$ & 38 & 27 & 2 & 67 \\
& \% Jantina & 56.7 & 40.3 & 3 & 100 \\
& \%Pendapatan & 41.3 & 64.3 & 100 & 49.3 \\
\multirow{5}{*}{ Perempuan } & $\mathrm{N}$ & 54 & 15 & 0 & 69 \\
& \% Jantina & 78.3 & 21.7 & 0 & 100 \\
& \%Pendapatan & 58.7 & 35.7 & 0 & 50.7 \\
& N & 92 & 42 & 2 & 136 \\
& \% Jantina & 67.6 & 30.9 & 1.5 & 100 \\
& \%Pendapatan & 100 & 100 & 100 & 100 \\
\hline
\end{tabular}

Jadual 11 menunjukkan taburan kekerapan responden mengikut tempoh perkhidmatan dalam kalangan penjawat awam di MAMPU Putrajaya. Jumlah responden tertinggi iaitu sebanyak 36 (26.5\%) orang responden yang berkhidmat bagi dua tempoh perkhidmatan iaitu 6 tahun hingga 10 tahun dan 11 tahun hingga 15 tahun. Sebanyak 33 (24.3\%) orang responden yang terdiri daripada 16 orang lelaki dan 17 orang perempuan telah berkhidmat selama tempoh 5 tahun dan ke atas. Seterusnya, sebanyak 18 $(13.2 \%)$ orang responden yang terdiri daripada 7 orang lelaki dan 11 orang perempuan telah berkhidmat selama 16 tahun hingga 20 tahun. Akhir sekali, minoriti responden iaitu seramai 13 (9.6\%) orang responden yang terdiri daripada 9 orang lelaki dan 4 orang perempuan telah berkhidmat 25 tahun dan ke atas. 
Jadual 11: Crosstabulation Jantina dan Tempoh Perkhidmatan

\begin{tabular}{|c|c|c|c|c|c|c|c|}
\hline & & & Tempo & Perkh & dmatal & & \\
\hline & Item & 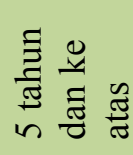 & 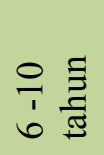 & $\begin{array}{l}\stackrel{n}{ \pm} \\
=\end{array}$ & 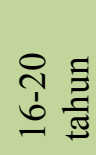 & 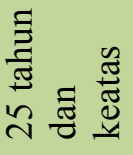 & Jumlah \\
\hline I elaki & $\mathrm{N}$ & 16 & 17 & 18 & 7 & 9 & 67 \\
\hline Lelak1 & $\%$ Jantina & 23.9 & 25.4 & 26.9 & 10.4 & 13.4 & 100 \\
\hline & \%Tempoh Perkhidmatan & 48.5 & 47.2 & 50 & 38.9 & 69.2 & 49.3 \\
\hline Peremnuan & $\mathrm{N}$ & 17 & 19 & 18 & 11 & 4 & 69 \\
\hline Perempuan & $\%$ Jantina & 24.6 & 27.5 & 26.1 & 15.9 & 5.8 & 100 \\
\hline & \%Tempoh Perkhidmatan & 51.5 & 52.8 & 50 & 61.1 & 30.8 & 50.7 \\
\hline Jumlah & $\mathrm{N}$ & 33 & 36 & 36 & 18 & 13 & 136 \\
\hline & $\%$ Jantina & 24.3 & 26.5 & 26.5 & 13.2 & 9.6 & 100 \\
\hline & \%Tempoh Perkhidmatan & 100 & 100 & 100 & 100 & 100 & 100 \\
\hline
\end{tabular}

\section{Analisis Tahap Prestasi Kerja}

Jadual 12 menunjukkan hasil analisis tahap motivasi dalam kalangan kakitangan MAMPU, Putrajaya. Nilai minimum bagi pembolehubah yang dikaji adalah 3.54 dan menunjukkan tahap prestasi yang tinggi. Kiraan min adalah berdasarkan tahap prestasi kepada 136 responden. Nilai maksimum bagi hasil pembolehubah prestasi kerja adalah 5.00 dan nilai sisihan piawai adalah sebanyak 0.24307 . Purata bagi nilai pembolehubah prestasi kerja adalah sebanyak 4.7121 dan menunjukkan bahawa tahap prestasi bagi kakitangan awam di MAMPU, Putrajaya berada pada tahap yang tinggi.

Jadual 12: Hasil Analisis Deskriptif bagi Prestasi Kerja

\begin{tabular}{lcccc}
\hline Pembolehubah & Minimum & Maksimum & Sisihan Piawai & Purata \\
\hline Prestasi Kerja & 3.54 & 5.00 & 0.24307 & 4.7121 \\
\hline
\end{tabular}

\section{Analisis Tahap Kepuasan Bekerja}

Jadual 13 menunjukkan hasil analisis deskriptif bagi tahap kepuasan kerja dalam kalangan kakitangan di MAMPU, Putrajaya. Nilai min bagi tahap kepuasan kerja adalah sebanyak 3.67 manakala nilai maksimum adalah 5.00. Nilai sisihan piawai adalah 0.26825 dan nilai purata adalah sebanyak 4.7377 . Berdasarkan nilai min di atas tahap prestasi penjawat awam di MAMPU, Putrajaya adalah sangat tinggi.

Jadual 13: Hasil Analisis Deskriptif bagi Tahap Kepuasan Kerja

\begin{tabular}{lcccc}
\hline Pembolehubah & Minimum & Maksimum & Sisihan Piawai & Purata \\
\hline Kepuasan Kerja & 3.67 & 5.00 & 0.26825 & 4.7377 \\
\hline
\end{tabular}

\section{Analisis Perkaitan antara Motivasi dan Prestasi Kerja terhadap Kepuasan Kerja}

$\mathrm{H}_{01} \quad$ Tidak terdapat perkaitan yang signifikan di antara motivasi dengan kepuasan kerja

$\mathrm{H}_{02} \quad$ Tidak terdapat perkaitan yang signifikan di antara prestasi kerja dengan kepuasan kerja

Jadual 14 menunjukkan analisis perkaitan antara motivasi dan prestasi kerja terhadap kepuasan bekerja dalam kalangan penjawat awam di MAMPU, Putrajaya. Hasil analisis korelasi bagi perkaitan antara motivasi terhadap terhadap kepuasan bekerja telah menunjukkan $(\mathrm{r}=0.357, \mathrm{p}<0.05)$ dengan tahap kekuatan hubungan yang cukup. Oleh itu, kajian ini menolak hipotesis $\mathrm{H}_{01}$ dimana tiada hubungan antara tahap motivasi dan kepuasan kerja dalam kalangan penjawat awam di MAMPU, Putrajaya. Manakala, hasil analisis kolerasi bagi perkaitan prestasi kerja terhadap kepuasan bekerja telah 
DOI: https://doi.org/10.47405/mjssh.v5i10.520

menunjukkan hubungan positif yang signifikan dengan prestasi kerja $(\mathrm{r}=.545, \mathrm{P}<0.05)$. Justeru, kajian turut menolak hipotesis $\mathrm{H}_{02}$ dimana tiada hubungan antara tahap prestasi kerja dan kepuasan kerja dalam kalangan penjawat awam di MAMPU Putrajaya. Secara keseluruhan, hubungan korelasi antara dua pembolehubah ini menunjukkan korelasi yang cukup kuat.

Jadual 14: Analisis Perkaitan antara Motivasi dan Prestasi Kerja

\begin{tabular}{llccc}
\hline & Item & Motivasi & Prestasi Kerja & $\begin{array}{c}\text { Kepuasan } \\
\text { Kerja }\end{array}$ \\
\hline \multirow{3}{*}{ Motivasi } & Korelasi Pearson & 1 & $.175^{*}$ & $.357^{* *}$ \\
& Sig. (2-tailed) & & .041 & .000 \\
& $N$ & 136 & 136 & 136 \\
\multirow{3}{*}{ Prestasi Kerja } & Korelasi Pearson & $.175^{*}$ & 1 & $.545^{* *}$ \\
& Sig. (2-tailed) & .041 & & .000 \\
& $N$ & 136 & 136 & 136 \\
\multirow{5}{*}{ Kepuasan Kerja } & Korelasi Pearson & $.357^{* *}$ & $.545^{* *}$ & 1 \\
& Sig. (2-tailed) & .000 & .000 & 136 \\
\hline
\end{tabular}

* Correlation is significant at the 0.05 level (2-tailed).

** Correlation is significant at the 0.01 level (2-tailed).

\section{Analisis Perbezaan Motivasi, Prestasi Kerja dan Kepuasan Kerja mengikut Jantina}

$\mathrm{H}_{01.1} \quad$ Tiada perbezaan di antara motivasi dengan jantina;

$\mathrm{H}_{01.2} \quad$ Tiada perbezaan di antara prestasi kerja dengan jantina;

$\mathrm{H}_{01.3} \quad$ Tiada perbezaan di antara kepuasan kerja dengan jantina;

Jadual 15 menunjukan hasil tiada perbezaan yang signifikan jantina dengan motivasi nilai $\mathrm{t}(134)=$ $1.426, \mathrm{p}=0.06>0.05$, prestasi kerja dengan nilai $\mathrm{t}(134)=0.203, \mathrm{p}=0.513>0.05$, dan kepuasan kerja dengan nilai t $(134)=0.933, \mathrm{p}=0.46>0.05$. Oleh yang demikian, ketiga-tiga hipotesis diterima iaitu $\mathrm{H}_{01.1:}$ tiada perbezaan motivasi dengan jantina; $\mathrm{H}_{01.2:}$ tiada perbezaan prestasi kerja dengan jantina; dan $\mathrm{H}_{01.3:}$ tiada perbezaan kepuasan kerja dengan jantina.

Jadual 15: Analisis Perbezaan Motivasi, Prestasi Kerja dan Kepuasan Kerja dengan Jantina

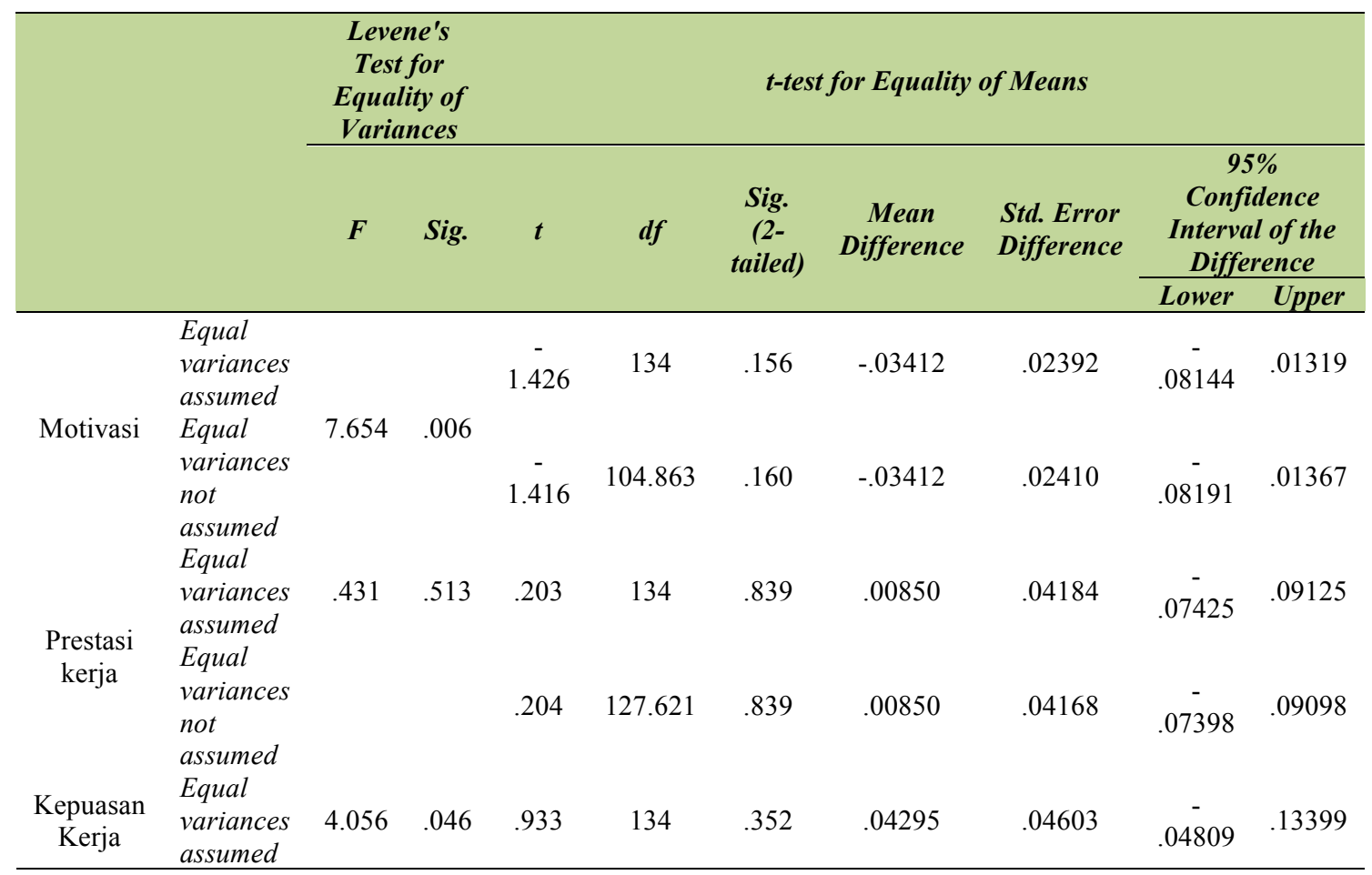


DOI: https://doi.org/10.47405/mjssh.v5i10.520

\begin{tabular}{|c|c|c|c|c|c|c|c|}
\hline $\begin{array}{l}\text { Equal } \\
\text { variances } \\
\text { not } \\
\text { assumed }\end{array}$ & .936 & 129.074 & .351 & .04295 & .04588 & $\begin{array}{c}- \\
.04782\end{array}$ & .13372 \\
\hline
\end{tabular}

\section{Analisis Perbezaan Motivasi, Prestasi Kerja dan Kepuasan Kerja denga Umur}

$\mathrm{H}_{02.1} \quad$ Tiada perbezaan di antara motivasi dengan umur;

$\mathrm{H}_{02.2} \quad$ Tiada perbezaan di antara prestasi kerja dengan umur;

$\mathrm{H}_{02.3} \quad$ Tiada perbezaan di antara kepuasan kerja dengan umur;

Jadual 16 menunjukkan analisis perbezaan antara umur dalam mempengaruhi motivasi dan prestasi kerja terhadap kepuasan kerja dalam kalangan penjawat awam di MAMPU, Putrajaya. Berdasarkan jadual di atas, hasil analisis menunjukkan tiada perbezaan yang signifikan antara umur dan motivasi dengan nilai $\mathrm{F}=0.79, \mathrm{p}=0.971>0.05$. Justeru, dapat disimpulkan hasil kajian ini menyokong hipotesis $\mathrm{H}_{02.1}$ tiada perbezaan di antara motivasi denmgan umur.

Jadual 16: Analisis Perbezaan Motivasi, Prestasi Kerja dan Kepuasan Kerja dengan Umur

\begin{tabular}{clccccc}
\hline Variables & \multicolumn{1}{c}{ Item } & $\begin{array}{c}\text { Sum of } \\
\text { Squares }\end{array}$ & $\boldsymbol{d f}$ & $\begin{array}{c}\text { Mean } \\
\text { Square }\end{array}$ & $\boldsymbol{F}$ & Sig. \\
\hline \multirow{3}{*}{ Motivasi } & Between Groups & .005 & 3 & .002 & .079 & .971 \\
& Within Groups & 2.642 & 132 & .020 & & \\
& Total & 2.647 & 135 & & & \\
& Between Groups & .528 & 3 & .176 & 3.119 & .028 \\
Prestasi Kerja & Within Groups & 7.448 & 132 & .056 & & \\
& Total & 7.976 & 135 & & & \\
Kepuasan & Between Groups & 1.333 & 3 & .444 & 7.000 & .000 \\
Bekerja & Within Groups & 8.381 & 132 & .063 & & \\
& Total & 9.714 & 135 & & & \\
\hline
\end{tabular}

Namun begitu, hasil analisis bagi perbezaan prestasi kerja dan kepuasan bekerja dengan umur dalam kalangan penjawat awam di MAMPU, Putrajaya menunjukkan perbezaan yang signifikan dengan nilai $\mathrm{F}=3.119, \mathrm{p}=0.028<0.05$ bagi prestasi kerja dan nilai $\mathrm{F}=7.000, \mathrm{p}=0.000<0.05$ bagi kepuasan kerja. Justeru berdasarkan jadual diatas, hipotesis pengkaji ditolak iaitu $\mathrm{H}_{02.2}$ tiada perbezaan di antara prestasi kerja dengan umur dan $\mathrm{H}_{02.3}$ Tiada perbezaan di antara kepuasan kerja dengan umur.

\section{Analisis Perbezaan Motivasi, Prestasi Kerja dan Kepuasan Kerja dengan Status Perkahwinan}

$\mathrm{H}_{03.1} \quad$ Tiada perbezaan di antara motivasi dengan status perkahwinan;

$\mathrm{H}_{03.2} \quad$ Tiada perbezaan di antara prestasi kerja dengan status perkahwinan;

$\mathrm{H}_{03.3} \quad$ Tiada perbezaan di antara kepuasan kerja dengan status perkahwinan;

Jadual 17 menunjukkan analisis perbezaan status perkahwinan dalam mempengaruhi motivasi dalam kalangan penjawat awam di MAMPU Putrajaya. Hasil kajian mendapati bahawa tiada perbezaan yang signifikan bagi motivasi denagn nilai $\mathrm{t}(134)=-0.594, \mathrm{p}=0.216>0.05$, prestasi kerja dengan nilai nilai $\mathrm{t}(134)=-1.509, \mathrm{p}=0.85>0.05$, dan kepuasan kerja dengan nilai t $(134)=0.321, \mathrm{p}=0.062>$ 0.05 dengan status perkahwinan. Oleh itu, kajian ini menerima ketiga-tiga hipotesis dalam kajian ini ini iaitu $\mathrm{H}_{03.1}$ tiada perbezaan di antara motivasi dengan status perkahwinan; $\mathrm{H}_{03.2}$ tiada perbezaan di antara prestasi kerja dengan status perkahwinan; dan $\mathrm{H}_{03.3}$ tiada perbezaan di antara kepuasan kerja dengan status perkahwinan. 
DOI: https://doi.org/10.47405/mjssh.v5i10.520

Jadual 17: Analisis Perbezaan Motivasi, Prestasi Kerja dan Kepuasan Kerja dengan Status Perkahwinan

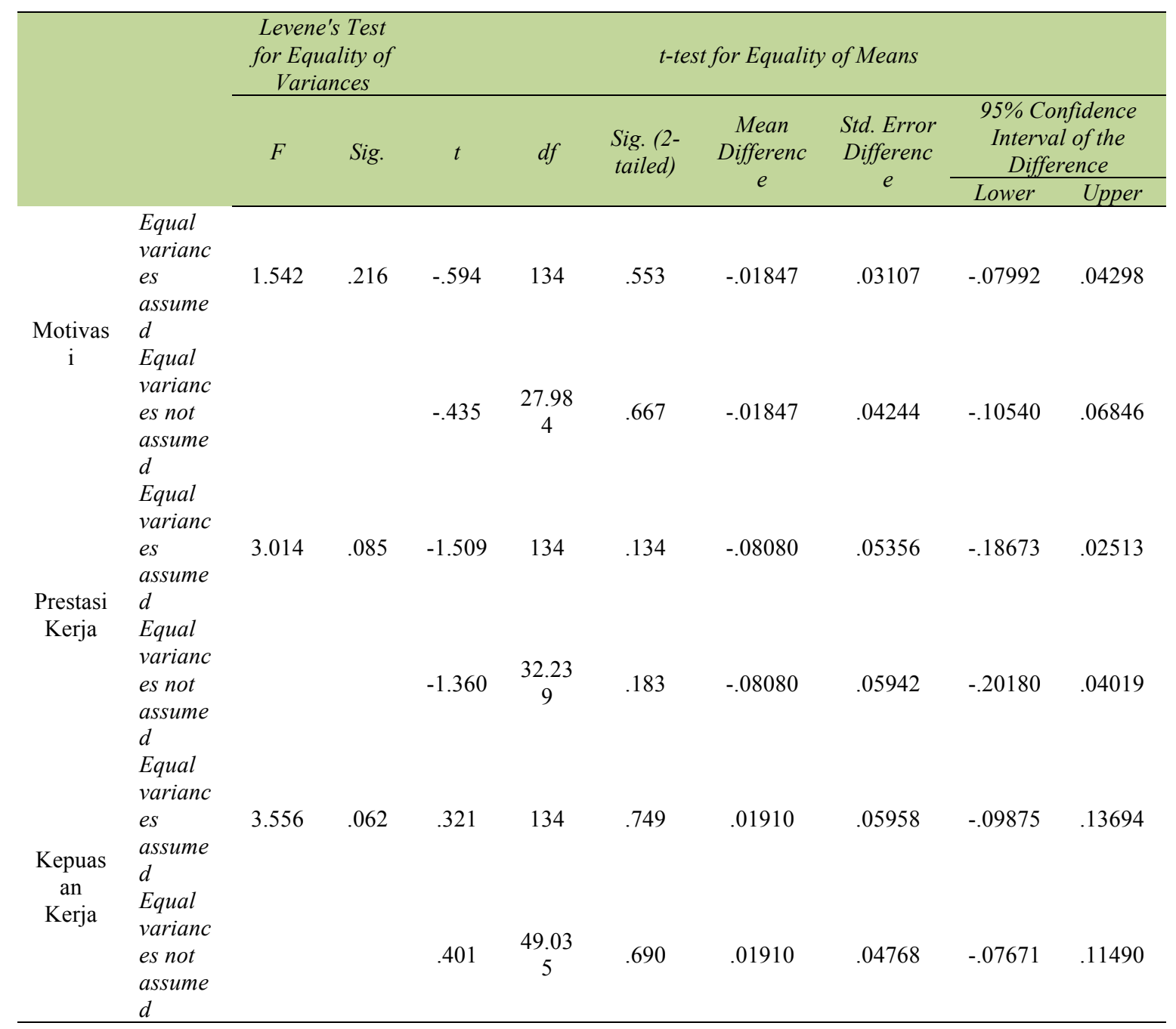

\section{Analisis Perbezaan Motivasi, Prestasi Kerja dan Kepuasan Kerja dengan Skim Perkhidmatan}

$\mathrm{H}_{04.1} \quad$ Tiada perbezaan di antara motivasi dengan skim perkhidmatan;

$\mathrm{H}_{04.2} \quad$ Tiada perbezaan di antara prestasi kerja dengan skim perkhidmatan;

$\mathrm{H}_{04.3} \quad$ Tiada perbezaan di antara kepuasan kerja dengan skim perkhidmatan;

Jadual 18 menunjukkan terdapat perbezaan yang signifikan di antara skim perkhidmatan dengan motivasi kerana nilai $\mathrm{F}=4.441, \mathrm{p}=0.014<0.05$; prestasi kerja dengan nilai $\mathrm{F}=16.528, \mathrm{p}=0.00<$ 0.05 ; dan kepuasan kerja dengan nilai $\mathrm{F}=25.741, \mathrm{p}=0.00<0.05$. Berdasarkan analisis kajian, ketigatiga hipotesis pengkaji ditolak kerana terdapat perbezaan di antara skim perkhidmatan dengan motivasi, prestasi kerja dan kepuasan kerja

Jadual 18: Analisis Perbezaan Motivasi, Prestasi Kerja dan Kepuasan Kerja dengan Skim Perkhidmatan

\begin{tabular}{llccccc}
\hline Variables & \multicolumn{1}{c}{ Item } & $\begin{array}{c}\text { Sum of } \\
\text { Squares }\end{array}$ & df & $\begin{array}{c}\text { Mean } \\
\text { Square }\end{array}$ & F & Sig. \\
\hline \multirow{3}{*}{ Motivasi } & Between Groups & .166 & 2 & .083 & 4.441 & .014 \\
& $\begin{array}{l}\text { Within Groups } \\
\text { Total }\end{array}$ & 2.481 & 133 & .019 & & \\
\hline
\end{tabular}


DOI: https://doi.org/10.47405/mjssh.v5i10.520

\begin{tabular}{clccccc}
\hline Prestasi & Between Groups & 1.588 & 2 & .794 & 16.528 & .000 \\
kerja & Within Groups & 6.388 & 133 & .048 & & \\
& Total & 7.976 & 135 & & & \\
Kepuasan & Between Groups & 2.711 & 2 & 1.355 & 25.741 & .000 \\
Kerja & Within Groups & 7.003 & 133 & .053 & & \\
& Total & 9.714 & 135 & & & \\
\hline
\end{tabular}

\section{Analisis Perbezaan Motivasi, Prestasi Kerja dan Kepuasan Kerja dengan Tahap Pendidikan}

$\mathrm{H}_{05.1} \quad$ Tiada perbezaan di antara motivasi dengan tahap pendidikan;

$\mathrm{H}_{05.2} \quad$ Tiada perbezaan di antara prestasi kerja dengan tahap pendidikan;

$\mathrm{H}_{05.3} \quad$ Tiada perbezaan di antara kepuasan kerja dengan tahap pendidikan;

Jadual 19 menunjukkan terdapat pebezaan yang signifikan di antara tahap pendidikan dengan motivasi iaitu dengan nilai nilai $\mathrm{F}=2.455, \mathrm{p}=0.037<0.05$; prestasi kerja dengan nilai nilai $\mathrm{F}=12.917, \mathrm{P}=$ $0.000<0.05 ;$ dan kepuasan kerja dengan nilai $\mathrm{F}=10.689, \mathrm{p}=0.000<0.05$. Ketiga-tiga hipotesis pengkaji tidak dapat diterima kerana terdapat perbezaan yang signifikan di antara motivasi, prestasi kerja dan kepuasan kerja dengan skim perkhidmatan.

Jadual 19: Analisis Perbezaan Motivasi, Prestasi Kerja dan Kepuasan Kerja dengan Skim Perkhidmatan

\begin{tabular}{clccccc}
\hline Variables & \multicolumn{1}{c}{ Item } & $\begin{array}{c}\text { Sum of } \\
\text { Squares }\end{array}$ & df & $\begin{array}{c}\text { Mean } \\
\text { Square }\end{array}$ & F & Sig. \\
\hline \multirow{3}{*}{ Motivasi } & Between Groups & .228 & 5 & .046 & 2.455 & .037 \\
& Within Groups & 2.418 & 130 & .019 & & \\
& Total & 2.647 & 135 & & & \\
Prestasi & Between Groups & 2.647 & 5 & .529 & 12.917 & .000 \\
Kerja & Within Groups & 5.329 & 130 & .041 & & \\
& Total & 7.976 & 135 & & & \\
Kepuasan & Between Groups & 2.830 & 5 & .566 & 10.689 & .000 \\
Kerja & Within Groups & 6.884 & 130 & .053 & & \\
\hline
\end{tabular}

\section{Analisis Perbezaan Motivasi, Prestasi Kerja dan Kepuasan Kerja dengan Pendapatan}

$\mathrm{H}_{06.1} \quad$ Tiada perbezaan di antara motivasi dengan pendpatan ;

$\mathrm{H}_{06.2} \quad$ Tiada perbezaan di antara prestasi kerja dengan pendapatan;

$\mathrm{H}_{06.3} \quad$ Tiada perbezaan di antara kpuasan kerja dengan pendapatan;

Berdasarkan Jadual 20, hasil analisis perbezaan antara motivasi dengan pendaptan menunjukkan tidak terdapat perbezaan yang signifikan dengan nilai $\mathrm{F}=0.542, \mathrm{P}=0.583>0.05$. Justeru, hipotesis pengkaji iaitu $\mathrm{H}_{06.1}$ tiada perbezaan di antara motivasi dengan pendapatan adalah diterima. Walau bagaimanapun terdapat perbezaan yang signifikan di antara pendaptan dengan prestasi kerja dengan nilai $\mathrm{F}=3.470, \mathrm{p}=0.034<0.05$; dan kepuasan kerja $\mathrm{F}=3.988, \mathrm{p}=0.021<0.05$. Oleh itu, hipotesis $\mathrm{H}_{06.2}$ tiada perbezaan di antara prestasi kerja dengan pendpatan; dan $\mathrm{H}_{06.3}$ tiada perbezaan di antara kepuasan kerja dengan pendapatan ditolak.

Jadual 20: Analisis Perbezaan Motivasi, Prestasi Kerja dan Kepuasan Kerja dengan Pendapatan

\begin{tabular}{ccccccc}
\hline Variables & Item & $\begin{array}{c}\text { Sum of } \\
\text { Squares }\end{array}$ & df & $\begin{array}{c}\text { Mean } \\
\text { Square }\end{array}$ & F & Sig. \\
\hline Motivasi & Between Groups & .021 & 2 & .011 & .542 & .583 \\
\hline
\end{tabular}



DOI: https://doi.org/10.47405/mjssh.v5i10.520

\begin{tabular}{llccccc} 
& Within Groups & 2.625 & 133 & .020 & & \\
& Total & 2.647 & 135 & & & \\
& Between Groups & .396 & 2 & .198 & 3.470 & .034 \\
& Within Groups & 7.581 & 133 & .057 & & \\
& Total & 7.976 & 135 & & & \\
Kepuasan & Between Groups & .550 & 2 & .275 & 3.988 & .021 \\
& Within Groups & 9.165 & 133 & .069 & & \\
& Total & 9.714 & 135 & & & \\
\hline
\end{tabular}

\section{Analisis Perbezaan Motivasi, Prestasi Kerja dan Kepuasan Kerja dengan Pendapatan}

$\mathrm{H}_{07.1} \quad$ Tiada perbezaan di antara motivasi dengan tempoh perkhidmatan;

$\mathrm{H}_{07.2} \quad$ Tiada perbezaan di antara prestasi kerja dengan tempoh perkhidmatan;

$\mathrm{H}_{07.3} \quad$ Tiada perbezaan di antara kepuasan kerja dengan tempoh perkhidmatan;

Jadual 21 menunjukkan terdapat perbezaan yang signifikan di antara kepuasan kerja dengan tempoh perkhidmatan dengan nilai $\mathrm{F}=3.776, \mathrm{p}=0.006<0.05$. Oleh itu, $\mathrm{H}_{07.3}$ tiada perbezaan di antara kepuasan kerja dengan tempoh perkhidmatan adalah ditolak. Walau bagaimanapun, tidak terdapat perbezaan yang signifikan di antara tempoh perkhidmatan dengan motivasi dengan nilai $\mathrm{F}=0.512, \mathrm{p}=$ $0.727>0.05$; dan prestasi kerja $\mathrm{F}=1.011, \mathrm{p}=0.404>0.05$. Oleh itu, $\mathrm{H}_{07.1}$ tiada perbezaan di antara motivasi dengan tempoh perkhidmatan; dan $\mathrm{H}_{07.2}$ tiada perbezaan di antara prestasi kerja dengan tempoh perkhidmatan adalah diterima.

Jadual 21: Analisis Perbezaan Motivasi, Prestasi Kerja dan Kepuasan Kerja dengan Tempoh Perkhidmatan

\begin{tabular}{clccccc}
\hline Variables & \multicolumn{1}{c}{ Item } & $\begin{array}{c}\text { Sum of } \\
\text { Squares }\end{array}$ & df & $\begin{array}{c}\text { Mean } \\
\text { Square }\end{array}$ & F & Sig. \\
\hline \multirow{3}{*}{ Motivasi } & Between Groups & .041 & 4 & .010 & .512 & .727 \\
& Within Groups & 2.606 & 131 & .020 & & \\
& Total & 2.647 & 135 & & & \\
Prestasi & Between Groups & .239 & 4 & .060 & 1.011 & .404 \\
Kerja & Within Groups & 7.737 & 131 & .059 & & \\
& Total & 7.976 & 135 & & & \\
Kepuasan & Between Groups & 1.004 & 4 & .251 & 3.776 & .006 \\
Kerja & Within Groups & 8.710 & 131 & .066 & & \\
& Total & 9.714 & 135 & & & \\
\hline
\end{tabular}

\section{Regresi Berganda}

Regresi berganda dijalankan untuk mengenal pasti hubungan antara pembolehubah tidak bersandar dan pembolehubah bersandar. Bagi kajian ini, terdapat dua pembolehubah tidak bersandar iaitu motivasi dan prestasi kerja manakala pembolehubah bersandar adalah kepuasan kerja. Hasil kajian bagi kedua-dua pembolehubah tidak bersandar menunjukkan bahawa pembolehubah tersebut mempunyai hubungan yang signifikan dengan pembolehubah bersandar iaitu kepuasan kerja.

Jadual 22: Analisis Regresi Berganda

\begin{tabular}{lccccc}
\hline & \multicolumn{2}{c}{$\begin{array}{c}\text { Unstandardized } \\
\text { Coefficients }\end{array}$} & $\begin{array}{c}\text { Standardized } \\
\text { Coefficients }\end{array}$ & t-value & Sig. \\
\hline Motivasi & $B$ & Std. Error & Beta & & \\
Prestasi & .517 & .134 & .270 & 3.850 & .000 \\
\hline
\end{tabular}




\begin{tabular}{l} 
Kerja \\
\hline$R$ Square $=0.367$ \\
Adjusted $R$ Square $=0.358 \quad$ F-Value $=38.612$ \\
Sig. $=0.00$
\end{tabular}

Hasil kajian menunjukkan bahawa nilai $R$ square bagi pembolehubah tidak bersandar adalah sebanyak 0.367 , manakala nilai adjusted $r$ square adalah 0.358 . Nilai $R$ square yang tinggi menunjukkan hubungan yang kuat antara pembolehubah tidak bersandar dan pembolehubah bersandar. Berdasarkan Jadual 22, menunjukkan bahawa pembolehubah ini signifikan (sig. $=0.000, \mathrm{p}<0.05$ ) dengan nilai $\mathrm{F}$ sebanyak 38.612. Motivasi mempunyai nilai beta 0.517 dan prestasi kerja mempunyai nilai beta sebanyak 0.549. Kedua-dua pembolehubah tidak bersandar adalah signifikan, namun prestasi kerja menunjukkan nilai beta yang tinggi berbanding nilai beta bagi motivasi. Justeru, dapat disimpulkan bahawa pembolehubah tidak bersandar (Prestasi kerja) mempunyai hubungan yang kuat dengan pembolehubah bersandar (Kepuasan kerja).

\section{Rumusan}

Berdasarkan hasil daripada analisis kajian ini, sebanyak 136 orang responden penjawat awam di MAMPU, Jabatan Perdana Menteri, Putrajaya telah terlibat dalam kajian ini. terdiri daripada perempuan dan telah berkahwin. Hasil kajian mendapati majoriti responden yang berumur 29 tahun hingga 38 tahun dan minoriti pula terdiri daripada responden yang berumur 48 hingga 60 tahun. Seterusnya, majoriti yang berkhidmat dalam skim perkhidmatan Pengurusan dan Profesional (Gred 41 -56) serta mempunyai Sarjana Muda sebagai tahap pendidikan tertinggi. Seterusnya dari segi gaji, majoriti responden tergolong dalam B40 dan mempunyai kadar gaji dari RM 1.000 hingga RM 4.360. Majoriti responden telah berkhidmat selama 6 hingga 10 tahun dan 11 hingga 15 tahun.

Dalam kajian penyelidikan ini, terdapat dua faktor pembolehubah tidak bersandar iaitu motivasi dan prestasi kerja manakala pembolehubah tidak bersandar adalah kepuasan kerja. Justeru, dalam kajian ini pengkaji telah menganalisis tahap motivasi, prestasi kerja dan kepuasan kerja dalam kalangan penjawat awam di MAMPU, Jabatan Perdana Menteri, Putrajaya. Berdasarkan hasil analisis tersebut, menunjukkan bahawa pembolehubah tidak bersandar motivasi mempunyai nilai min yang tinggi iaitu sebanyak 4.00, diikuti dengan tahap prestasi kerja sebanyak 3.54 dan akhir sekali kepuasan kerja mempunyai skor sebanyak 3.67.

Seterusnya, pengkaji juga telah menjalankan analisis perkaitan antara motivasi dan prestasi kerja terhadap kepuasan kerja. Berdasarkan analisis penyelidikan, pengkaji mendapati bahawa pembolehubah tidak bersandar prestasi kerja mempunyai hubungan korelasi yang kuat iaitu $r=0.545$, $\mathrm{p}<0.05$ manakala motivasi pula menunjukkan hubungan korelasi yang cukup iaitu $\mathrm{r}=0.357, \mathrm{p}<0.05$. Justeru, kedua-dua hipotesis pengkaji tidak dapat diterima kerana terdapat perkaitan hubungan antara motivasi dan prestasi kerja dalam mempengaruhi kepuasan kerja dalam kalangan penjawat awam di MAMPU. Jabatan Perdana Menteri, Putrajaya. Selain itu, pengkaji juga telah menjalankan analisis perbezaan diantara latar belakang (jantina, umur, status perkahwinan, skim perkhidmatan, gaji, tahap pendidikan dan tempoh perkhidmatan) dalam mempengaruhi motivasi, prestasi kerja terhadap kepuasan kerja.

Dapatan kajian mendapati bahawa tiada perbezaan yang signfikan di antara motivasi, prestasi kerja dan kepuasan kerja dengan jantina. Apabila nilai $p>0.05$ maka tiada perbezaan yang signifikan dapat disimpulkan. Hasil kajian menunjukkan bahawa nilai p bagi motivasi adalah sebanyak 0.06 , manakala nilai $\mathrm{p}$ bagi prestasi kerja adalah sebanyak 0.513 serta nilai $\mathrm{p}$ bagi kepuasan kerja adalah sebanyak 0.46. Justeru, ketiga-tiga hipotesis telah diterima kerana tiada perbezaan yang signifikan di antara jantina dengan ketiga-tiga pembolehubah.

Analisis kajian juga telah menunjukkan bahawa tiada perbezaan yang signifikan motivasi dengan umur kerana nilai $\mathrm{p}=0.971>0.05$. Namun begitu, terdapat perbezaan yang signifikan di antara prestasi kerja dan kepuasan kerja denagn umur dengan nilai $\mathrm{p}=0.028<0.05$ dan $\mathrm{p}=0.000<0.05$. Dapatan kajian menunjukkan bahawa umur boleh mempengaruhi prestasi kerja dan kepuasan kerja 
seseorang individu. Justeru, hipotesis pengkaji telah ditolak kerana terdapat perbezaan yang signifikan di antara umur dengan prestasi kerja dan kepuasan kerja.

Pengkaji turut menjalankan analisis penyelidikan perbezaan di antara motivasi, prestasi kerja dan kepuasan dengan status perkahwinan. Berdasarkan kajian yang telah dibuat, tiada perbezaan yang signifikan kerana nilai $\mathrm{p}>0.05$. Justeru ketiga-tiga hipotesis dapat diterima dan status perkahwinan jelas tidak mempengaruhi motivasi, prestasi kerja dan kepuasan kerja. Seterusnya, analisis perbezaan motivasi, prestasi kerja dan kepuasan kerja dengan skim perkhidmatan menunjukkan terdapat perbezaan yang signifikan kerana nilai $\mathrm{p}<0.05$.

Analisis perbezaan di antara motivasi, prestasi kerja dan kepuasan kerja dengan tahap pendidikan menunjukkan perbezaan yang signfikan. Hal ini disebabkan oleh nilai $\mathrm{p}<0.05$, justeru ketiga-tiga hipotesis yang menyatakan tiada perbezaan di antara telah ditolak. Dapatan kajian juga mendapati tiada perbezaan yang signifikan di antara motivasi dengan pendapatan namun terdapat perbezaan yang signfikan di antara prestasi kerja dan kepuasan kerja dengan pendpatan.

Akhir sekali, pengkaji telah melakukan analisis regresi berganda untuk menguji pembolehubah tidak bersandar (motivasi dan prestasi kerja). Berdasarkan hasil penyelidikan, prestasi kerja mempunyai hubungan yang kuat dengan kepuasan kerja kerana nilai beta yang tinggi iaitu sebanyak (0.549) berbanding dengan motivasi yang mempunyai nilai beta sebanyak $(0.517)$. Justeru dapat disimpulkan bahawa, prestasi kerja boleh mempengaruhi tahap kepuasan kerja dalam kalangan penjawat awam di MAMPU Jabatan Perdana Menteri, Putrajaya.

Kepuasan kerja merupakan pemboleh ubah yang kerap digunakan oleh para pengkaji untuk dikaji. Terdapat beberapa faktor yang menyebabkan kajian dilakukan ke atas pembolehubah kepuasan kerja. Faktor yang pertama adalah kerana terdapat perkaitan budaya kerja yang terhubung dengan hak asasi manusia. Setiap individu yang bekerja merupakan modal insan yang berhak mendapatkan ganjaran, pampasan, penghargaan atau insentif meningkatkan kepuasan kerja. Faktor yang kedua, kepuasan kerja adalah pengukur kepada motivasi dan prestasi kerja seseorang individu melalui tingkah laku kerja.

Seterusnya, prestasi kerja yang dipamerkan oleh kakitangan penjawat awam MAMPU yang berkhidmat di Putrajaya merupakan refleksi terhadap kepuasan kerja seseorang individu. Pengukur tahap prestasi seseorang penjawat awam yang berstatus tetap adalah melalui Laporan Nilaian Prestasi Tahunan (LNPT) yang dilakukan setiap tahun. Menurut, Handoko (2001) menyatakan, hubungan antara kepuasan kerja dan prestasi kerja merupakan sistem yang berlanjutan. Prestasi kerja yang cemerlang yang ditunjukkan seseorang penjawat awam layak diberikan penghargaan.

Motivasi kerja yang tinggi memberi impak yang positif kepada jabatan terutamanya dari segi produktiviti. Penjawat awam akan lebih menghargai kerja yang dilakukan, menghasilkan kerja yang bermutu serta melahirkan modal insan yang berkualiti. Secara tuntasnya, hasil kajian dijalankan memperlihatkan terdapat perkaitan motivasi dan prestasi kerja terhadap kepuasan kerja di MAMPU, JPM, Putrajaya.

\section{Penghargaan}

Penghargaan kepada Unit Pemodenan Tadbiran dan Perancangan Pengurusan Malaysia (MAMPU), Jabatan Perdana Menteri, Putrajaya atas kesudian untuk berkerjasama untuk menghasilkan Disertasi Bacelor FEM4959-A \& B sebagai memenuhi syarat bergraduat dalam Bacelor Sains Pembangunan Manusia, Fakulti Ekologi Manusia, Universiti Putra Malaysia. 


\section{Rujukan}

Abassi, S. M. \& Hollman, K.W. (2000). Turnover: The real bottom line. Public Personnel Management, 2(3), 333-342

Aziri, B. (2008). Job Satisfaction: A Literature Review. Management Research and Practice, 3(4), 77-86

Beilock, R., \& Capelle, R. (1990). Occupational loyalties among truck drivers.

Bockerman, P. \& Pekka, I. (2009). Job Disamenities, Job Satisfaction, Quit Intentions, andActual Separations: Putting the Pieces Together. Industrial Relations, 48(1), 73-96.

Bohlander, G., Snell, S. \& Sherman, A. (2001). Managing HumanResources. South-Western College Publishing. Thomson Learning.

Boxall, P., Macky, K., and Rasmussen, E. (2003), 'Labour turnover and retention in New ,Zealand: The causes and consequences of leaving and staying with employers', Asia Pacific Journal of Human Resources, 41, 195-214.

Bozeman, B., \& Gaughan, M. (2011). Job Satisfaction among University Faculty: Individual, Work, and Institutional Determinants. The Journal of Higher Education 82(2), 154-186. doi:10.1353/jhe.2011.0011.

Bright, L. (2008), Does public service motivation really make a difference on the job satisfaction and turnover intentions of public employees? American Review of Public Administration, 38, 2, 149166.

Briner, R. B. (2000) Relationships between work environments, psychological environments and psychological well-being: in-depth review. Occup. Med. 50(5), 299-303. Retrieved from http://occmed.oxfordjournals.org/content/50/5/299.full.pdf

Brown, G. D. A., Jonathan G., Andrew, O. \& Jing Q. (2008). Does Wage Rank AffectEmployees' Well-being?. Industrial Relations, 47(3), 355-89.

Busck, O., Knudsen, H., \& Lind, J. (2010). The transformation of employee participation: Consequences for the work environment. Economic and Industrial Democracy, 31, 285-305.

Campbell, J.P., Dunnette, M.D., Lawler, E.E., \& Weick, K.E. (1970). Managerial Behaviour, Performance, and Effectiveness. New York: McGraw-Hill.

Clark, A \& Oswald, A. (1996). Satisfaction and Comparison Income. Journal of Public Economics, $61,359-81$

Clark, A, Nicolas Kristensen, \& Niels Westergard-Nielsen. (2009). Job Satisfaction and Co-Worker Wages:Status or Signal?. Economic Journal, 119: 430-47

Cob, C. M. S. C., Halim, B. A., \& Amin, A. (2017). Faktor-Faktor Yang Mempengaruhi Prestasi Kerja Dalam Kalangan Penjawat Awam: Satu Kajian Teoritikal Factors Affecting Job Performance amongst Public Servants: A Theoretical Study.

Davis, K. and Nestrom, J.W. (1985). Human Behavior at work: Organizational Behavior, 7 edition, McGraw Hill, New York, p.109

De Jonge, J, \& Wilmar S., (1998). Job Characteristics and Employee Well-Being. Journal of Organizational Behaviour, 19(4), 387-407.

Fuller MA, Valacich JS, \& George JF (2008). Information Systems Project Management: A Process and Team Approach. Upper Saddle River, New Jersey: Pearson Prentice Hall

George, J.M. \& Jones, G.R. (2008). Understanding and Managing Organizational behavior, Fifth Edition,

Gustafsson, R.A. \& Szebehely, M. (2009). Outsourcing of elder care services in Sweden: effects on work environment and political legitimacy', in Paid Care in Australia. Politics, profits practices, eds D. King and G. Meagher, Sydney: Sydney University Press, pp. 81-112.

Pearson/Prentice Hall, New Yersey, p. 78 M.B. Frye (2004). Equity-based compensation for employees: firm performance and determinants. Journal of Financial Research, 27 (2004), pp. $31-54$

Hasbi, R. (2001) Perkaitan kepuasan kerja dengan prestasi kerja di kalangan pekerja di industri pembuatan. Master's thesis, Universiti Malaysia Sarawak.

Hassan, M. (2009). Business Management.1st ed. Kaduna: Joy publishers

Hoppock, R. (1935). Job Satisfaction, Harper and Brothers, New York, p. 47

Holpp, L. (2012). Win-Win Performance Appraisals. New York: The McGraw-Hill Companies, Inc.

Hvid, H. and Hasle, P. (2003), Human development and working life, Aldershot: Ashgate Publishing Limited. 
Idemobi, Ellis \& Onyeizugbe, Chinedu \& Akpunonu, Uju. (2011). Compensation Management as Tool for Improving Organizational Performance in the Public Sectors: A Study of the Civil Service of Anambra State of Nigeria. Sacha Journal of Policy and Strategic Studies, 1(1), 109120

Ismail, N., \& Abiddin, N. Z. (2010). Tinjauan faktor-faktor yang mempengaruhi komitmen pekerja terhadap organisasi. Dinamika Sosial Ekonomi, 6 (1).

Judge, T. A., Thoresen, C. J., Bono, J. E., \& Patton, G. K. (2001). The job satisfaction-job performance relationship: A qualitative and quantitative review. Psychological Bulletin, 127, $376-407$.

Judge, T. A., Locke, E. A., Durham, C. C., \& Kluger, A. N. (1998). Dispositional Effects on Job and Life Satisfaction: The Role of Core Evaluations. Journal of Applied Psychology, 83,

Kaliski, B.S. (2007). Encyclopedia of Business and Finance, Second edition, Thompson Gale, Detroit.

Kasran, Siti Barokah (1999) Hubungan antara sistem penilaian prestasi dan prestasi kerja di DBKU dan Telekom, Kuching. Master's thesis, Universiti Malaysia Sarawak.

Linz, Susan J. (2003). Job Satisfaction Among Russian Workers. International Journal of Manpower, 24(6), 626-52

Lynne, W. (2012). Raising Performance through Motivation, Part One: Content Theories. Michael Heath Consulting

Mathew (2003). People power. Education times the time of india delhi febuary 3(5).

Milman, A. (2002). Hourly employee retention in the attraction industry: research from small and medium-sized facilities in Orlando, Florida", Journal of Leisure Property, 2(1), 40-51.

Mullins, J.L. (2005). Management and organizational behavior, Seventh Edition, Pearson Education Limited, Essex.

Nguyen A, Taylor J, Bradley S (2003). Relative Pay and Job Satisfaction. Some New Evidence, MPRA Paper No 1382.

Dawson P (1987).Computer Technology and the Job of the First-line Supervisor New Technology. Work Empl, 2(1), 47-59.

Noel, T. W. (2009). The Impact of Knowledge Resourcea on New Venture Performance. Journal of Small Business Management, 47(1), 1-22.

Nordin, N. \& Hassan, M. M. (2019a). Kerangka Kaedah Kajian Penyelidikan: Faktor-faktor yang Mempengaruhi Komitmen Prestasi Kerja. Malaysian Journal of Social Sciences and Humanities (MJSSH), 4(7), 111-121. doi: https://doi.org/10.47405/mjssh.v4i7.309.

Nordin, N. \& Hassan, M. M. (2019b). Faktor-faktor yang Mempengaruhi Komitmen Prestasi Kerja dalam kalangan Penjawat Awam. Kajian Rintis di Jabatan Kemajuan Masyarakat, Negeri Pulau Pinang. Malaysian Journal of Social Sciences and Humanities (MJSSH), 4(7), 11-20. doi: https://doi.org/10.47405/mjssh.v4i7.303.

Okpara, J. O. (2002) The influence of ethical climate types on job satisfaction of IT managers; Implications for management practice and development in a developing economy. Paper presented to the Academy of Business and Administrative Services Seventh International Conference, July 6-8, San Jose, Costa Rica.

Onukwube, H.N., 2012. Correlates of job satisfaction amongst quantity surveyors in consulting firms in Lagos, Nigeria. Aust. J. Construct. Econ. Build, 12, 43-54.

Opperman C. S. (2002). Tropical business issues. Partner Price Water House Coopers. International Business Review.

Pouliakas, K., \& Ioannis, T. (2010). Differences in the Job Satisfaction of High-Paid and Low-Paid Workers Across Europe. International Labour Review, 149(1), 1-29

Sell, L. \& Cleal, B. (2011). Job satisfaction, work environment, and rewards: Motivational theory revisited. Labour, 52, 1-23.

Skalli, A, Ioannis T., \& Efi V. (2008). Jobs as Lancaster Goods: Facets of Job Satisfaction and Overall Job Satisfaction. Journal of Socio-Economics, 37,1906-20

Sokoya, S.K. (2000). Personal predictors of job satisfaction for the public sector manager: Implications for Management practice and development in a developing Economy, The Journal of Business in Developing Nation, 4(1): Available online at: www.ewp.rpi.edu/jbdm.

Spector, P. E. (1997). Job satisfaction: Application, assessment, causes, and consequences. Thousand Oaks, CA: Sage Publication Inc 
Saraswathi, S. (2011): A Study on Factors that Motivate IT and Non-IT Sector Employees: A Comparison. International Journal of Research in Computer Application and Management, 1(2), $72-77$

Tamkin P (2005), The Contribution of Skills to Business Performance, DfES publication RW39, August 2005

Vroom, V.H. (1964). Work and motivation. Wiley.

Wegner, F. W, More, H. W., \& Miller, L. S. (2003). Effective Police Supervision, Cincinnati, Anderson Publishing Co.

Whiseand, P. \& Rush, G. (1988). Supervising Police Personnel: Back to Basics, Prentice Hall, New Jersey

Wood, S.J. and Wall, T.D. (2007), 'Work enrichment and employee voice in human resource management-performance studies', The International Journal of Human Resource Management $18,1335-1372$.

Yusuf N. \& Metiboba S. (2012). Work environment and job attitude among employees in a Nigerian work organization. Journal of Sustainable Society, 1(2), 36-43. 